\title{
Interim Report on Core Physics and Fuel Cycle Analysis of the Pebble Bed Reactor Power Plant Concept
}

\author{
D. R. Vondy
}

\section{OAK RIDGE NATIONAL LABORATORY}




\section{Printed in the United States of America. Available from National Technical Information Service \\ U.S. Department of Commerce 5285 Port Royal Road, Springfield, Virginia 22161 \\ Price: Printed Copy $\$ 5.25$; Microfiche $\$ 3.00$}

This report was prepared as an account of work sponsored by an agency of the United States Government. Neither the United States Government nor any agency thereof, nor any of their employees, contractors, subcontractors, or their employees, makes any warranty, express or implied, nor assumes any legal liability or responsibility for any third party's use or the results of such use of any information, apparatus, product or process disclosed in this report, nor represents that its use by such third party would not-infringe privately owned rights. 


\section{DISCLAIMER}

This report was prepared as an account of work sponsored by an agency of the United States Government. Neither the United States Government nor any agency Thereof, nor any of their employees, makes any warranty, express or implied, or assumes any legal liability or responsibility for the accuracy, completeness, or usefulness of any information, apparatus, product, or process disclosed, or represents that its use would not infringe privately owned rights. Reference herein to any specific commercial product, process, or service by trade name, trademark, manufacturer, or otherwise does not necessarily constitute or imply its endorsement, recommendation, or favoring by the United States Government or any agency thereof. The views and opinions of authors expressed herein do not necessarily state or reflect those of the United States Government or any agency thereof. 


\section{DISCLAIMER}

Portions of this document may be illegible in electronic image products. Images are produced from the best available original document. 
ORNL/TM-6142

Distribution Category UC-77

\author{
HTGR BASE TECHNOLOGY PROGRAM \\ Evaluation of GE Pebble Bed Reactor Concept \\ (189a 01441)
}

Neutron Physics Division

\title{
INTERIM REPORT ON CORE PHYSICS AND FUEL CYCLE ANALYSIS \\ OF THE PEBBLE BED REACTOR POWER PLANT CONCEPT
}

D. R. Vondy

Date Published - December 1977

Thas report was porice

sporsored by the finepare? as an aceount of aon

l'nuted States nor the States Goversment Nentmer the

bereg, nor any of the trated States Dopartment af

wastractors any of then employeds, no: ans of then

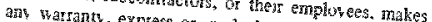

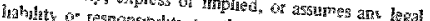

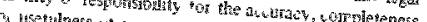

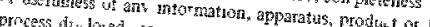

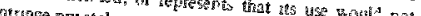

watringe protely nwned nghts

NOTICE This document contains information of a preliminary nature.

It is subject to revision or correction and therefore does not represent a inal report.

\author{
OAK RIDGE NATIONAL LABORATORY \\ Oak Ridge, Tennessee 37830 \\ operated by \\ UNION CARBIDE CORPORATION \\ for the \\ DEPARTMENT OF ENERGY
}


" 
Abstract ......................... 1

Introduction ........................ 1

Certain Basic Aspects . . . . . . . . . . . . . . 4

Notes on Economics ..................... 8

Temperature Coefficient ................ 11

Point Reactor Model Survey Results . . . . . . . . . . 11

Production of $\mathrm{U}^{233}$ Fuel .................... 23

Effect of Out-of-Core Hold Up on Fission Product Poison . . . . 28

One-Dimensional Survey Results . . . . . . . . . . . 31

Single Pebble Size Results . . . . . . . . . . . . 41

Early Operation ................. . . 46

Two-Dimensional Results . . . . . . . . . . . 50

Further Discussion . . . . . . . . . . . . . 54 
ABSTRACT

Calculations were made to predict the performance of a pebble bed reactor operated in a mode to produce fissile fuel (high conversion or breeding). Both a one pebble design and a design involving large primary feed pebbles and small fertile pebbles were considered. A relatively short residence time of the primary pebbles loaded with $\mathrm{U}^{23}$ fuel was found to be necessary to achieve a high breeding ratio, but this leads to relatively high fuel costs. A high fissile inventory is associated with a low $\mathrm{C} / \mathrm{Th}$ ratio and a high thorium loading, causing the doubling time to be long, even though the breeding ratio is high, and the fuel cost of electrical product to be high. Production of $U^{233}$ fuel from $U^{235}$ feed was studied and performances of the converter and breeder reactor concepts were examined varying the key parameters.

Introduction

This is an interim report on the independent review of the potential of the pebble bed reactor ${ }^{1}$ for producing fissile fuel. Primary consideration was given to the two pebble concept suggested by the General Electric Company $^{2}$ for achieving a higher breeding ratio than is indicated by German studies of the potential of modifications to the one pebble design of their AVR reactor.

We qualify the information presented herein due to the nature of this exploratory assessment and the low level of effort. Much of this effort was expended in familiarization with the behavior and neutronics characteristics of the reactor, tailoring the avallable analysis methods for the calculations and establishing a reasonable description of the reactor 
implied by the general concept in the form of computer code input data. Specific weaknesses in the calculations include the general areas of modeling of the reactor and the fuel management, calculation of the neutron flux distribution in space and energy for desired conditions, resonance shielding, fission product poisoning, reactor control, and sources of perturbation and their effects. Minor aspects have been ignored.*

We report results of simple calculations made to assess aspects of interest to this review in a way which facilitates understanding, done both by hand and by computer. ${ }^{3}$ Results are also reported which were obtained from rather sophisticated machine calculations using the code system which applies finite-difference diffusion theory (VENTURE neutronics) ${ }^{4}$ and carries out an exposure calculation (BURNER) ${ }^{5}$. An illustration of application of the continuous fueling, once through model is shown for $(R, Z)$ geometry in Fig. 1. Few group cross sections were generated with the AMPX 6 code system (NITAWL, XSDRNPM) using inhouse evaluated 123 group cross section data with resonance parameters. In the course of this effort the two computation systems were coupled to allow few group cross sections to be produced and a problem solved in a single computer run. Few group calculations were done with two, four and eight groups (one thermal group).

Herein, simple definitions have been used for conversion ratio and doubling time. For simplicity, $\mathrm{Pa}^{23^{3}}$ has been identified as a fuel nuclide for the one and two dimensional calculations so conversion (breeding) ratio was calculated as

$$
\mathrm{C}=\frac{\text { Capture rate } \operatorname{in} \mathrm{Th}^{232} \text { and } \mathrm{U}^{234}}{\text { Absorption rate in } \mathrm{U}^{233}, \mathrm{U}^{235} \text { and } \mathrm{Pa}^{233}} \text {. }
$$

Otherwise the $\mathrm{Pa}^{\text {is }}$ absorptions were counted as a loss in the numerator, without any nuclide importance weighting. Doubling times have been

\footnotetext{
*oxygen and silicon content and hence effects on neutron econony were ignored.
} 


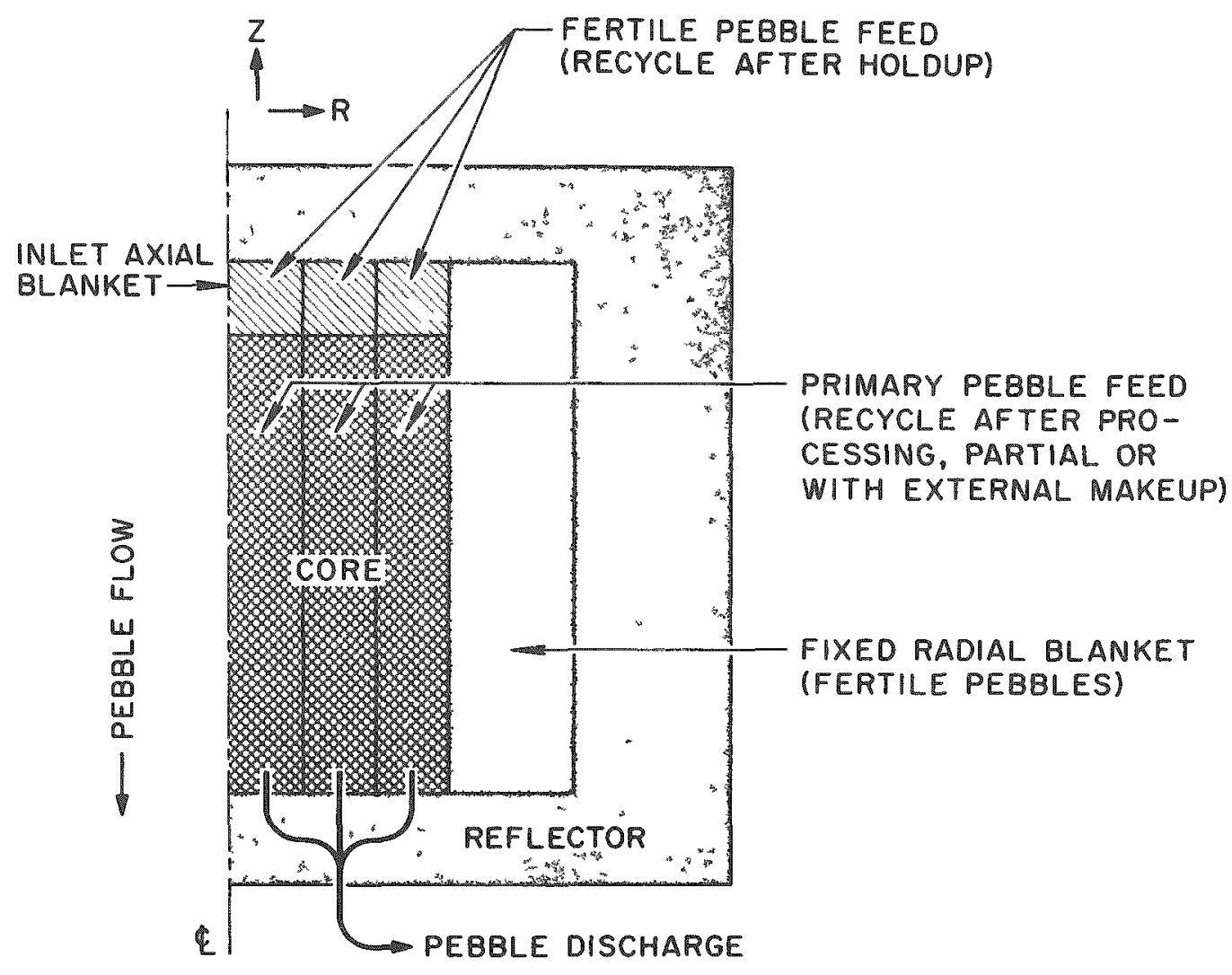

NOTE.

THIS IS AN ILLUSTRATION OF ONE OF THE MANY POSSIBILITIES.

THREE FLOW PATHS THROUGH AXIAL BLANKET AND CORE ARE SHOWN.

Fig. 1. The Once-Through, Continuous Fueling Mode1 
calculated for the fissile inventory doubling without considering availability for compounding nor allowing for extra inventory, but considering a plant load factor of 0.9 . Residence time is reported as at full power, but may also be used as that at the reduced power associated with a load factor $<1$.

In the results reported, the usually defined fissile nuclides $\left(U^{23}\right.$, $U^{235}$, etc.), those with thermal $n$ values $>1$, were given equal weights in fuel generation and use calculations.

\section{Certain Basic Aspects}

Consider that a breeder reactor is to be operated on primarily $\mathrm{U}^{23}$ fuel. This fuel must come from a reactor supplied with avallable fuel, probably highly enriched uranium, primarily $U^{23}$. There must be concern about where the $U^{23}$ feed material is to come from and how much contamination of the higher uranium isotopes it contalns. After a breeder reactor becomes operational it is deemed necessary for it to use its own product in recycle, and the excess used to fuel additional breeder reactors. Thus there are basically three different reactor fueling conditions of interest:

1) U $^{235}$ feed, high conversion,

2) Converter product as breeder feed, shifting to recycle of discharge, and

3) Excess breeder product as breeder feed, shifting to recycle of discharge.

Considering that only a relatively small breeding galn is expected for the reactor concept under study, the possible long term need for converters fed by breeders is not addressed due to its position far in the future, and 3) above is of small concern and not addressed.

Doubling time will be used here, or more usefully its reciprocal in yrs $^{-1}$ when the conversion ratio is less than unity, in the simple sense of 


$$
\frac{1}{T_{d}}=\frac{P u}{I \eta_{e}}(C-1) \frac{d F}{d E}
$$

where

$P$ is the design power level,

u is the load factor,

I is the associated fuel inventory,

$C$ is the conversion (breeding) ratio,

$\eta_{e}$ is the energy conversion efflciency, and

$\mathrm{dF} / \mathrm{dE}$ is the amount of fuel consumed per unit energy produced, consistent units required.

Note that for a breeder, the smaller the doubling time the better, or generally the more positive the reciprocal doubling time the better. Decreasing the energy conversion efficiency increases the reciprocal doubling time, but economics demand a high value of $\eta_{e}$ generally, except possibly for a converter to produce breeder fuel.

Considering the requirement for a steady state (critical) reactor on the average, the achievable conversion rat1o, In terms of effective reaction rates, is given by allowing maximum neutron capture in the fertile materla1. Using average reaction rates (fraction of total neutron losses over all nuclides of interest, possibly with special weighting),

$$
\begin{aligned}
& R=(n-1) A-2 H-L-Z-I \\
& C=F\left[\frac{(n-1) A-2 Z-L-Z-Y}{A}\right]
\end{aligned}
$$

where
$A$ is the neutron absorption rate in fuel,
$R$ is the neutron capture rate in fertile,
C is the conversion (breeding) ratio, 
F Is a factor to account for recovery loss (2 form chosen here for simplicity),

H is the loss rate of potential fuel $\left(\mathrm{Pa}^{23}\right.$ absorption removes a neutron and destroys a potential full atom, the effect of $U^{234}$ generation neglected,

I is the leakage loss rate,

$Z$ is a relatively set neutron absorption rate (C, structure, $\mathrm{Xe}$ ),

$Y$ is the loss rate to fisston products, nearly linear with exposure, and

$\eta$ is the fissile effective vof/oa.

Thus an approximation for the reciprocal doubling time is

$$
\frac{1}{T_{d}}=\frac{P U F}{I n_{e}}\left[\frac{(n-1) A-2 H-L-Z-Y}{A}-1\right] \frac{d F}{d E} .
$$

Iinear perturbations may be directly assessed,

$$
\frac{\Delta C}{\Delta x} \simeq \frac{F}{\partial x}\left[\frac{(n-1) A-2 H-L-Z-Y}{A}\right] \text {. }
$$

For example, changing the $\mathrm{Pa}^{23}$ absorption rate gives

$$
\Delta C \simeq \frac{-2 F}{A}(\Delta H) \text {. }
$$

Fuxther

$$
\frac{\Delta\left[\frac{1}{\left(T_{d}\right)}\right]}{\Delta x} \simeq \frac{\partial}{\partial x}\left\{\frac{P u F}{I \eta_{e}}\left[\frac{(\eta-1) A-2 H-L-Z-Y}{A}\right] \frac{d F}{d E}\right\} .
$$

For example

$$
\frac{\Delta\left[\frac{1}{\left(T_{d}\right.}\right]}{\frac{1}{\left(T_{d}\right)}} \simeq \frac{-2 \Delta H}{[(n-1) A-2 H-L-Z-Y]},
$$

or for a range where $T_{d}+0$, for two conditions considering only change in $H$,

$$
\frac{T_{d 2}}{T_{d 1}}=\left[\frac{(n-1) A-2 H_{1}-L-Z-Y}{(n-1) A-2 H_{2}-L-Z-Y}\right]
$$


Simple calculations with the base data in use yield the following results of $n$ for $\mathrm{U}^{233}, \mathrm{U}^{235}$ fuel wixtures as dependent on the fast to thermal flux rat1o:

\begin{tabular}{c|c|cccccc}
\multicolumn{1}{c|}{$\begin{array}{c}\text { Eraction } \\
U^{233}\end{array}$} & $\begin{array}{c}\mid c \\
\text { Absorption } \\
U^{235}\end{array}$ & 0 & 1 & 2.5 & 5. & 7.5 & 10 \\
\hline 1.0 & 0. & 2.243 & 2.233 & 2.218 & 2.197 & 2.171 & 2.155 \\
0.9 & 0.1 & 2.223 & 2.208 & 2.191 & 2.167 & 2.138 & 2.117 \\
0.5 & 0.5 & 2.142 & 2.108 & 2.084 & 2.046 & 2.004 & 1.966 \\
0.1 & 0.9 & 2.060 & 2.007 & 1.977 & 1.925 & 1.870 & 1.815 \\
0 & 1.0 & 2.040 & 1.982 & 1.950 & 1.895 & 1.836 & 1.777 \\
\hline
\end{tabular}

Note that subtracting unity from $n$ places an upper bound on the possible value of the conversion (breeding) ratio. Unavoidable losses reduce this; a one percent loss to fission products reduces the conversion ratio by about 2 percent while a one percent loss to $\mathrm{Pa}^{23}$ reduces the conversion ratio by about 4 percent. The flux ratio for a value of $\mathrm{C} / \mathrm{Th}$ of 80 is estimated at near 5, and a reduction in the conversion ratio of .0027 is estimated for each percent of the absorptions in $U^{235}$ of the total fuel absorptions.

other factors affecting the conversion ratio are examined later. Much of the effort in this study was concentrated on a design having a carbon to thorium ratio of 80 in the reactor core and a reactor size of $\left.1,500 \mathrm{Mw} \mathrm{e}^{(3,750 \mathrm{Mw}} \mathrm{th}\right)$ with a power density of $6.25 \mathrm{~W}_{\mathrm{th}} / \mathrm{cc}$. The results obtained for these conditions indicated that a higher C/Th was needed to reduce the fissile inventory, so a value of 110 was then used. Also it appeared that a power density of $5 \mathrm{w}_{\mathrm{th}} / \mathrm{cc}$ is more reasonable, so the plant power level was reduced to $1,200 \mathrm{Mw}$ e $\left(3,000 \mathrm{Mw}_{\mathrm{th}}\right)$ for a core volume of $6 \times 10^{8} \mathrm{cc}$. 


\section{Notes on Economics}

Simple economic analysis was done. Unit costs used here were $200 \$ / \mathrm{kgm}$ fabrication, $150 \$ / \mathrm{kgm}$ processing, shipping and waste disposal, and a plant load factor of 0.9 . For a net conversion ratio of unity (after losses) the direct fuel costs would be zero. The direct fabrication and processing costs are given on the basis of one gram of fuel as

$$
X \simeq \frac{350 L}{7.884 W_{e}^{T} r}
$$

where

L is the heavy metal loading, $\mathrm{gm} / \mathrm{cc}$,

$W_{e}$ is the power density, electrical w/cc, full power,

$\mathrm{T}_{\mathrm{r}}$ is the residence time, years at reduced power,

$$
7.884=8760 \times 0.9 \div 10^{3} \text {, and }
$$

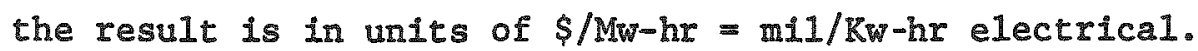

This cost is shown below for a loading of $0.2 \mathrm{gm} / \mathrm{cc}$ as dependent on the power density and residence time for $\eta_{e}=0.4$ :

\begin{tabular}{c|c|c|c|c|c}
\multicolumn{3}{c}{$\mathrm{W}_{\mathrm{th}} / \mathrm{cc}$} & $\mathrm{W}_{\mathrm{e}} / \mathrm{cc}$ & 0.5 & \multicolumn{5}{c}{ Residence time (yrs) } \\
\cline { 3 - 6 } 3 & 1.2 & 14.8 & 7.4 & 3.7 & 1.9 \\
6 & 2.4 & 7.4 & 3.7 & 1.8 & 0.9 \\
9 & 3.6 & 4.9 & 2.5 & 1.2 & 0.6 \\
\hline
\end{tabular}

Note that for either low power density or short residence time, the direct cost for treating the fuel becomes quite uncompetitive.

Similarly the indirect charges for the fuel are quite dependent on power density and residence time. With the assumptions of a net conversion 
(breeding) ratio of unity and one-half year lead time and one year delay in recovery. for a fissile loading of $G \mathrm{gm} / \mathrm{cc}$ and an interest rate of 1 annually, the Indirect cost of fuel inventory worth $35 \$ / g n\left(U^{233}\right)$ amounts to

$$
Y \simeq \frac{35,000 \mathrm{iG}}{7.884 \mathrm{~W}_{e}}\left[1+\frac{3}{2 \mathrm{~T}_{\mathrm{r}}}\right] \text {. }
$$

Results dependent on power density and core residence time for an interest charge of 0.1 and a fissile loading of $0.006 \mathrm{gm} / \mathrm{cc}$ are shown below:

Residence time (yrs)

\begin{tabular}{c|c|c|c|c|c}
\cline { 3 - 6 }$W_{t h} / c c$ & $W_{e} / c c$ & 0.5 & 1.0 & 2.0 & 4.0 \\
\hline 3 & 1.2 & 8.9 & 5.5 & 3.9 & 3.1 \\
6 & 2.4 & 4.4 & 2.8 & 1.9 & 1.5 \\
9 & 3.6 & 3.0 & 1.8 & 1.3 & 1.0 \\
\hline
\end{tabular}

Note that this indirect charge is also quite uncompetitive for low power density and short residence time. (Delay in recovery of fuel could also be examined directly since the indirect cost is essentially linear with the delay time.)

The sum of these two contributions is shown below:

\begin{tabular}{c|c|c|c|c|c}
\multicolumn{3}{c}{} & \multicolumn{5}{c}{ Residence time (yrs) } \\
\cline { 3 - 6 }$W_{\mathrm{th}} / \mathrm{cc}$ & $\mathrm{W}_{\mathrm{e}} / \mathrm{cc}$ & 0.5 & 1.0 & 2.0 & 4.0 \\
\hline 3 & 1.2 & 23.7 & 12.9 & 7.6 & 5.0 \\
6 & 2.4 & 11.8 & 6.4 & 3.8 & 2.5 \\
9 & 3.6 & 7.9 & 4.3 & 2.5 & 1.7 \\
\hline
\end{tabular}

Note that a required increase in fissile loading with residence time has been ignored. 
Operation of the plant at a power level below design does not affect the direct costs (residence time adjusted as the reciprocal of the load factor). However, the smaller the load factor the higher the indirect costs, an effect not considered above.

Increasing the out-of-core inventory makes two primary contributions to the fuel costs. Even if the fuel in this storage is allowed to build up (rather than being loaded with purchased fuel initially), more fuel must be purchased because of delay in recycle, and more of the pebbles must be purchased, even if they contain only fertile materlal. Indirect costs are Increased by delay in recovery of product value and by increase in fuel purchase (which simple economic models may not reflect).

A fifty percent increase in the amount of materlal which must be fabricated at the start of life increases the direct cost by the relative factor $y=1+.5 / N$ where $N$ is the number of loadings over the life, usually a small factor for $\mathbb{N}$ large. Discounting this to consider the total direct and indirect cost, the cost ratio is approximated by the factor $z=\frac{1.51+1-(1+1)^{1-N}}{1+1-(1+i)^{1-N}}$, where $i$ is the discount factor. For $1=.07$ and $N=15, z=1.051$, compared with the direct cost factor of $y=1.033$. These factors would also apply to a fissile inventory increase.

Deferred recovery incurs no direct cost. The effect of deferring return one reference period through the life is given by the relative recovery worth factor of $(1+i)^{-1}=0.935$. Expressing a one-year delay for the assumptions made above, the fuel cost contribution, relative to that without delay, is given by

$$
z=\left[\frac{2 T_{r}+5}{2 T_{r}+3}\right]
$$


and for a residence time of 2 years, $z=1.286$, quite significant.

A rather involved formulation results when an optimum out-of-core fertile pebble residence time is sought (to reduce $\mathrm{Pa}$ losses). It depends on the fissile content of these pebbles, and other factors and generally decreases as core residence time decreases. The economic optimum appears to be less than two $\mathrm{Pa}^{23}$ half-11ves ( $<60$ days). The decay of $\mathrm{I}^{135} \rightarrow \mathrm{Xe}^{135} \rightarrow$ also makes a significant contribution when the fissile content is significant.

Temperature Coefficient

The temperature coefflclents of reactivity were estimated with the AMPX codes considering only temperature rise in $\mathrm{Th}^{232}$ (the Doppler). For a one pebble model ak/kaT was $-7.5 \times 10^{-5} /{ }^{\circ} \mathrm{C}$ and for the two pebble mode1 it was $-5.7 \times 10^{-5}$ with one-fourth of the fertile material in the fertile pebbles, and $-7.9 \times 10^{-5}$ with three-fourths of the fertile material in the fertile pebble. The coefflcient would be smaller if part of the materlal were subjected to a lower temperature increase.

\section{Point Reactor Model Survey Results}

The point reactor model is useful for parameter studies. A number of simplifying assumptions were made for these calculations, including the exposure of successive batches of fuel feed to an effective two group flux and the estimate of a neutron balance from conditions at exposure of feed material to half the core residence time (one size pebble), with feed adjusted to satisfy a critical system. Thus advantages from the peaking of the flux toward the inlet of the reactor and hold up of fertile material outside of the reactor are not considered. On the other hand, no axial or radlal leakage losses were included in the base calculations 
so the result tends to place an upper bound on the achievable fuel breedIng (conversion) ratio. It may be of interest that certain seeningly trivial aspects make a contribution. It was found to be desirable to account for the increase in the fast to thermal flur ratio with exposure and enrichment (the increase with recycle contamination), and also the decrease in performance due to generation of $\mathrm{U}^{234}$ from $\mathrm{Pa}^{23}$ capture.

The fissile consumption rates for the primary fuel nuclides, needed to predict doubling time, ace estimated as follows in $\mathrm{Kgm} / \mathrm{MW}-\mathrm{yr}$ electrical at $m_{e}=0.4:$

\begin{tabular}{c|c|c|c}
$\phi_{1} / \phi_{2}$ & $v^{233}$ & $U^{235}$ & Average \\
\hline 0 & 1.075 & 1.153 & 1.114 \\
2.5 & 1.094 & 1.200 & 1.147 \\
5 & 1.113 & 1.247 & 1.180 \\
7.5 & 1.126 & 1.298 & 1.212 \\
10 & 1.140 & 1.349 & 1.224 \\
\hline
\end{tabular}

The reduction in conversion ratio due to absorption in $\mathrm{Pa}^{23}$ at equiIibrium concentration is estimated as

$$
\frac{\Delta C}{C}=\frac{-2}{\left(1+\frac{\lambda}{g}\right.}
$$

where $g$ is the specific absorption rate and $\lambda$ the decay constant for $\mathrm{Pa}^{233}$. This reduction is found to be relatively insensitive to the fast to thermal flux ratio for $0^{233}$ fuel. Dependence of this loss on the flux level 
associated with power density values for $U^{23}$ fuel is show below:

\begin{tabular}{c|c|c}
$W_{t h} / c c$ & $w_{t h} / g m t^{233}$ & $\frac{-2}{\left(1+\frac{\lambda}{g}\right)}$ \\
\hline 3 & 590 & -0.028 \\
6 & 1130 & -0.052 \\
9 & 1640 & -0.075 \\
\hline
\end{tabular}

Thus there is incentive to hold down the flux level when a high breeding ratio is desired. This reduction would be decreased by short core residence time, hold up of fertile balls outside of the reactor before recycle, and flux peaking toward the inlet.

The effect of neutron absorption in fission products on the conversion ratio was estimated for clean $U^{233}$ feed, $(\Delta C)$ as shown below for a power density of $6.25 \mathrm{~W}_{\mathrm{th}}$ /cc as dependent on residence time:

\begin{tabular}{l|c|c|c|c|c}
\multicolumn{1}{c}{ Fission Product } & 0.5 & 1.0 & 1.5 & 2.0 & 2.5 \\
\cline { 2 - 6 } $\mathrm{Xe}^{135}$ & .0337 & .0329 & .0322 & .0315 & .0309 \\
$\mathrm{Nd}^{143}$ & .0025 & .0046 & .0064 & .0080 & .0095 \\
$\operatorname{Prg}^{147}$ & .0029 & .0051 & .0067 & .0079 & .0088 \\
$\operatorname{Pm}^{148}$ & .0004 & .0008 & .0010 & .0011 & .0013 \\
$\operatorname{Pm}^{148}$ & .0009 & .0015 & .0020 & .0024 & .0026 \\
$\operatorname{Sm}^{149}$ & .0082 & .0091 & .0098 & .0104 & .0107 \\
Others & .0228 & .0429 & .0639 & .0829 & .1010 \\
\hline
\end{tabular}

The above numbers are absorptions relative to absorptions in fissile, some factor of about 2.2 times the fraction of total absorptions. Evident$1 y$ a short core residence time would be necessary to achieve a high breeding ratio. 
Values of reactivity importance for the key nuclides at a one year exposure time for $\mathrm{U}^{23}$ feed are show below using flux, adjoint weighting but excluding neutron transport and scattering contributions:

\begin{tabular}{|c|c|c|c|}
\hline Nuclide & $\frac{\partial k}{k \partial N}$ & $\frac{\mathrm{N} \partial \mathrm{k}}{\mathrm{k} \partial \mathrm{N}}$ & $\begin{array}{c}\text { Eraction } \\
\text { Neutron } \\
\text { Loss }\end{array}$ \\
\hline $\mathrm{Th}^{232}$ & $-9.59+02$ & -.4728 & .4512 \\
\hline $\mathrm{Pa}^{233}$ & $-1.72+04$ & -.0128 & .0114 \\
\hline $\mathrm{U}^{233}$ & $3.21+04$ & .4590 & .4510 \\
\hline$U^{234}$ & $-1.35+04$ & -.0128 & .0125 \\
\hline$U^{235}$ & $1.76+04$ & .0016 & .0022 \\
\hline$U^{236}$ & $-5.88+03$ & - & - \\
\hline C & $-1.87-01$ & -.0075 & .0062 \\
\hline$X e^{135}$ & $-8.33+07$ & -.0181 & .0143 \\
\hline $\mathrm{Nd}^{143}$ & $-1.31+04$ & -.0045 & .0036 \\
\hline $\operatorname{Pm}^{147}$ & $-4.80+04$ & -.0037 & .0036 \\
\hline $\operatorname{Pm}^{148}$ & $-1.14+06$ & -.0005 & .0005 \\
\hline $\mathrm{Pm}^{148 \mathrm{~m}}$ & $-7.40+05$ & -.0011 & .0011 \\
\hline $\operatorname{Sm}^{149}$ & $-2.73+06$ & -.0059 & .0047 \\
\hline other $\mathrm{fp}$ & $-2.01 \div 03$ & -.0405 & .0376 \\
\hline
\end{tabular}

Such data is useful for study of perturbations. For example the relative importance of $U^{233}$ to $U^{235}$, and hence an estimate of relative economic worth, is 1.82 , and for $U^{234}$ relative to $U^{235}$ it is -0.77 (without credit for its fertile potential), and -0.33 for $\mathrm{U}^{236}$.

The above table lists the nuclides treated in most of this study. Not shown are $I^{135}$ and $\mathrm{Pm}^{149}$, required for short exposures, the "other fission products" were treated as two lumped components, and the nucl1des $U^{230}$ through the $\mathrm{Pu}$ chain to $\mathrm{Am}^{243}$ were treated for $\mathrm{U}^{235}$ feed. 
Shown In Fig. 2 is the estimated conversion (breeding) ratio as dependent on the core residence time through a thirty year history with $0^{233}$ fuel Indtally and product recycle without delay. A decrease in residence time increases the breeding ratio. The effect of delay in rew cycle is an Increase in the reference time for this data. Thus setting the delay time equal to the residence time would cause two successive batches InItially with identical exposure histories, and this would propagate through the history: the thirty year history as shown becomes a sixty year history, or a thirty year history is reached at the reference of fifteen years without delay. Thus the abscissa scale time numbers should be multiplied by the ratio of the exposure plus delay time to the exposure time, different for each case, quite generally increasing the breeding ratio at the expense of more $\mathrm{U}^{233}$ feed.

The increase in conversion ratio early in the history is not fully understood; it may be in part a fallacy of the model. However, as Th232 absorptions are replaced in part by a small amount of $\mathrm{U}^{234}$ absorptions, the $\mathrm{Pa}^{233}$ losses decrease. It appears that importance values should be assigned to the fuels to disadvantage the worth of $\mathrm{U}^{235}$ in the calculation.

Shown below are estimates of the fuel cost for the thirty year history as dependent on core residence time. Init values for $\mathrm{Th}^{232}, \mathrm{U}^{233}$, $\mathrm{U}^{234}, \mathrm{U}^{235}$ and $\mathrm{U}^{236}$ of $.025,35,-5,25$ and -10 \$/gn were used, $\$ 200 / \mathrm{kgm}$ fabrication, $\$ 150 / \mathrm{kgm}$ processing, .5 year lead and $1.0 \mathrm{lag}$ times, 0.9 plant factor, and 0.1 Interest rate (indirect cost) with discounting at a factor of 0.07 . Higher values of unit fabrlcation and processing costs of course increase the fuel cost and shift the optimum toward longer residence time. The results are shown on Page 17. 


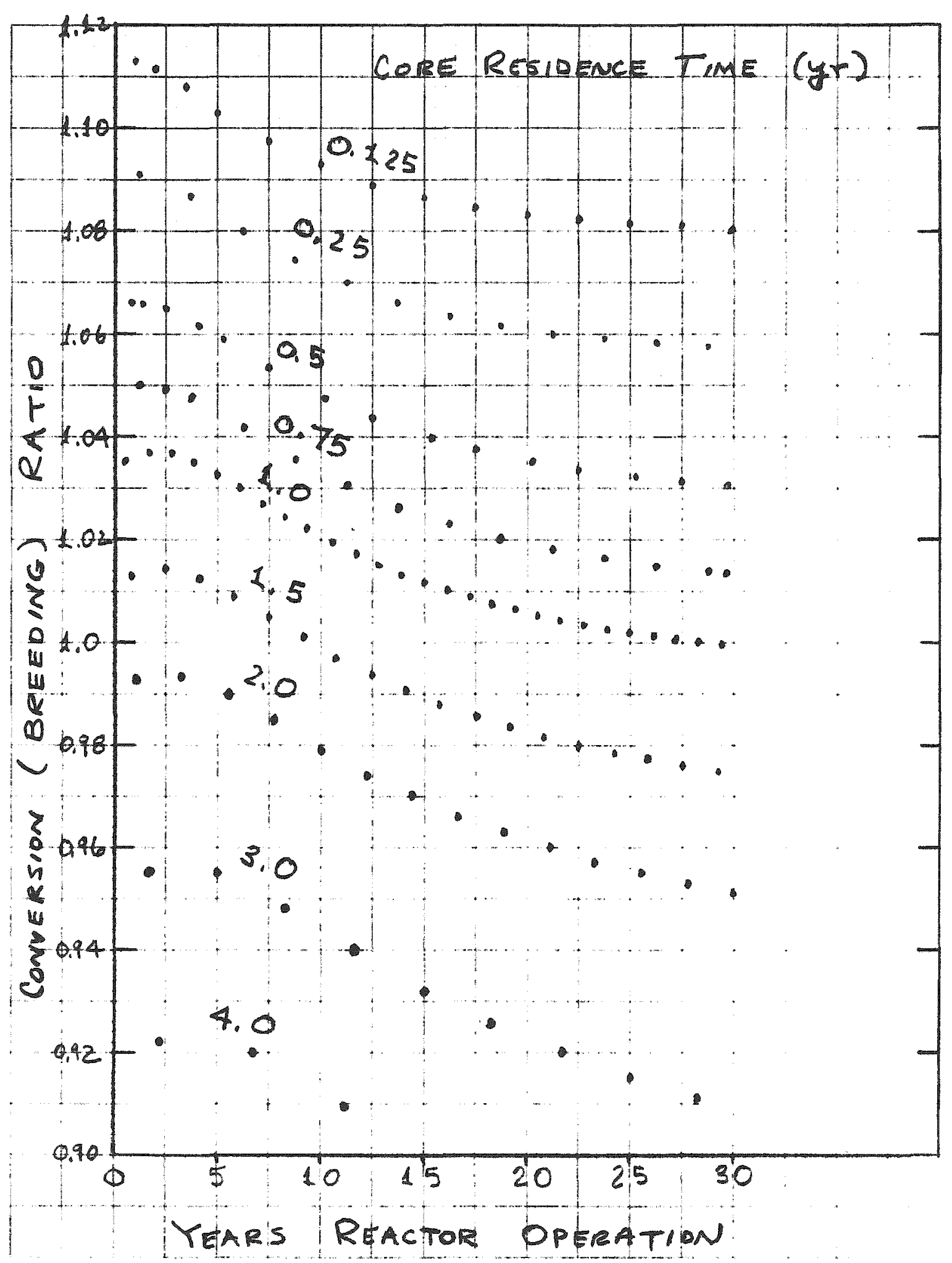

Fig. 2. Behavior with $\mathrm{U}^{233}$ Feed and Product Recycle 


\begin{tabular}{|c|c|c|c|c|c|c|}
\hline \multirow{2}{*}{$\begin{array}{l}\text { Core } \\
\text { Residence } \\
\text { Time (yr) }\end{array}$} & \multirow{2}{*}{$\begin{array}{c}\text { Recycle } \\
\text { Delay } \\
\text { (cycles) }\end{array}$} & \multicolumn{2}{|c|}{ Flssile Data } & \multirow{2}{*}{$\begin{array}{l}\text { Effective } \\
\text { Conversion } \\
\text { Ratio }\end{array}$} & \multirow{2}{*}{$\begin{array}{l}\text { Effective } \\
\text { Reciprocal } \\
\text { Doubling } \\
\text { Time (yr-1) }\end{array}$} & \multirow{2}{*}{$\begin{array}{c}\text { Fue1 } \\
\text { Cost } \\
\text { (mil/kw } e^{-k x)}\end{array}$} \\
\hline & & $\begin{array}{c}\text { Feed } \\
\text { Rate } \\
\left(\mathrm{gm} / \mathrm{Rw}_{\mathrm{e}}^{-\mathrm{yr}}\right) \\
\end{array}$ & $\begin{array}{c}\text { Loading } \\
\left(\mathrm{gm} / \mathrm{KW}_{\mathrm{e}}\right)\end{array}$ & & & \\
\hline .125 & 0 & 18.09 & 2.25 & 1.090 & .0398 & 36.93 \\
\hline .25 & 0 & 9.51 & 2.39 & 1.067 & .0283 & 19.18 \\
\hline .5 & 0 & 5.02 & 2.49 & 1.041 & .0165 & 10.27 \\
\hline .75 & 0 & 3.46 & 2.57 & 1.026 & .0099 & 7.31 \\
\hline 1. & 0 & 2.66 & 2.63 & 1.013 & .0050 & 5.84 \\
\hline 1.5 & 0 & 1.86 & 2.76 & 0.991 & -.0033 & 4.44 \\
\hline \multirow[t]{3}{*}{2.} & 0 & 1.48 & 2.93 & 0.969 & -.0106 & 3.80 \\
\hline & $1 / 2$ & 1.42 & 2.80 & 0.975 & -.0085 & 3.77 \\
\hline & 1 & 1.37 & 2.67 & 0.981 & -.0067 & 3.73 \\
\hline 3. & 0 & 1.10 & 3.10 & 0.930 & -.0216 & 3.28 \\
\hline 4. & 0 & 0.93 & 3.44 & 0.891 & -.0297 & 3.18 \\
\hline
\end{tabular}

These cost estimates do not reflect any difference from the delay in recycle due to increase in the inventory because the economic model fires the lag time and charges unit costs of feed nuclides and credits discharge. Only the effect of differences in unit values for the nuclides, and the amounts, enter the calculation, so these results indicate that the reference unit values of the nuclides are not accurately determined for this situation involving two year exposure; $0^{233}$ probably has a higher value relative to $\mathrm{v}^{235}$, but the other unit values also play a role.

The above results were recast to approximate the performance with a recycle delay of one year. The time varlation through the history is 
shown in Figure 3 and data for these historles is shown below:

\begin{tabular}{|c|c|c|c|c|}
\hline $\begin{array}{l}\text { Core } \\
\text { Residence } \\
\text { Time }(y x)\end{array}$ & $\begin{array}{r}\text { External } \\
\mathrm{U}^{233} \text { Feed } \\
\left(\mathrm{gm} / \mathrm{Kw}_{\mathrm{e}}^{-\mathrm{yr})}\right.\end{array}$ & $\begin{array}{l}\text { Effective } \\
\text { Conversion } \\
\text { Ratio }\end{array}$ & $\begin{array}{c}\text { Effective } \\
\text { Reciprocal } \\
\text { Doubling } \\
\text { Time (yr-1) }\end{array}$ & $\begin{array}{l}\text { Fue1 Cost } \\
\left(\mathrm{mL1} / \mathrm{K} \mathrm{w}_{r}-\mathrm{hr}\right)\end{array}$ \\
\hline .125 & 0.074 & 1.112 & 0.0494 & 35.87 \\
\hline .25 & 0.079 & 1.087 & 0.0368 & 19.18 \\
\hline .5 & 0.086 & 1.058 & 0.0233 & 10.05 \\
\hline .75 & 0.090 & 1.040 & 0.0155 & 7.16 \\
\hline 1. & 0.093 & 1.025 & 0.0096 & 5.74 \\
\hline 1.5 & 0.100 & 0.999 & -0.0004 & 4.37 \\
\hline 2. & 0.102 & 0.977 & -0.0078 & 3.75 \\
\hline 3. & 0.120 & 0.936 & -0.0190 & 3.26 \\
\hline 4. & 0.130 & 0.903 & -0.0264 & 3.15 \\
\hline
\end{tabular}

Note the increase in the amount of $\cup^{233}$ which must be supplied from an external source as the residence time is increased and as the lag time for recycle is increased.

The effect on performance of neutron losses not accounted for in a simple model may be taken into account. Show in Fig. 4 is the dependence of the breeding ratio on the residence time and the additional neutron loss fraction, without provision for delay in recycle of the produced uranium calculated for thirty year reactor histories. The range chosen extends to negative values of the additional losses in the event that dimensional calculations show the losses to be overestimated (possibly lower fission product losses due to the skewed flux distribution toward the inlet). Shown in Fig. 5 is the dependence of reciprocal doubling time on these other losses. 


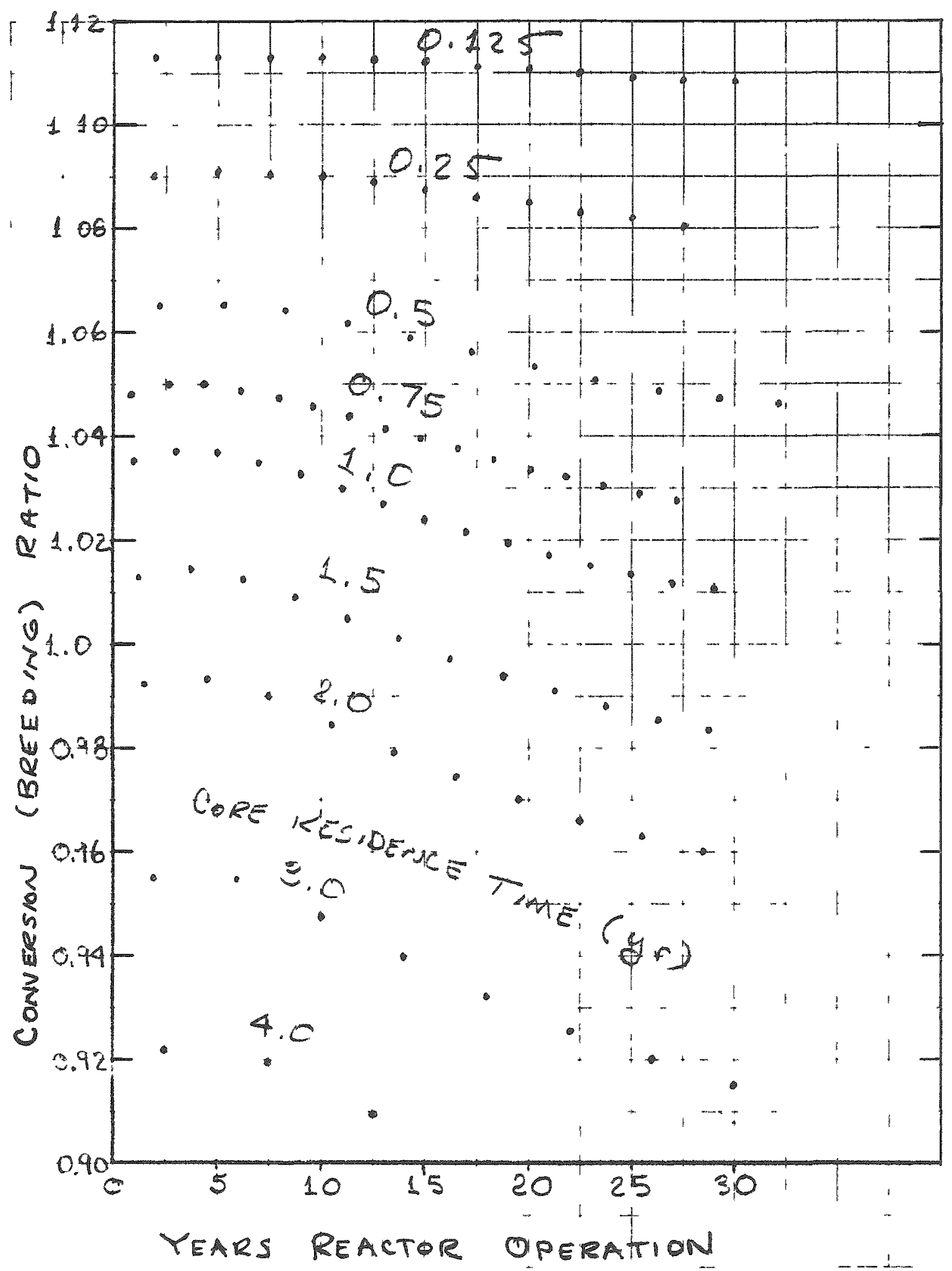

Fig. 3. Behavior with $U^{23}$ Feed and Delayed Product Recycle 


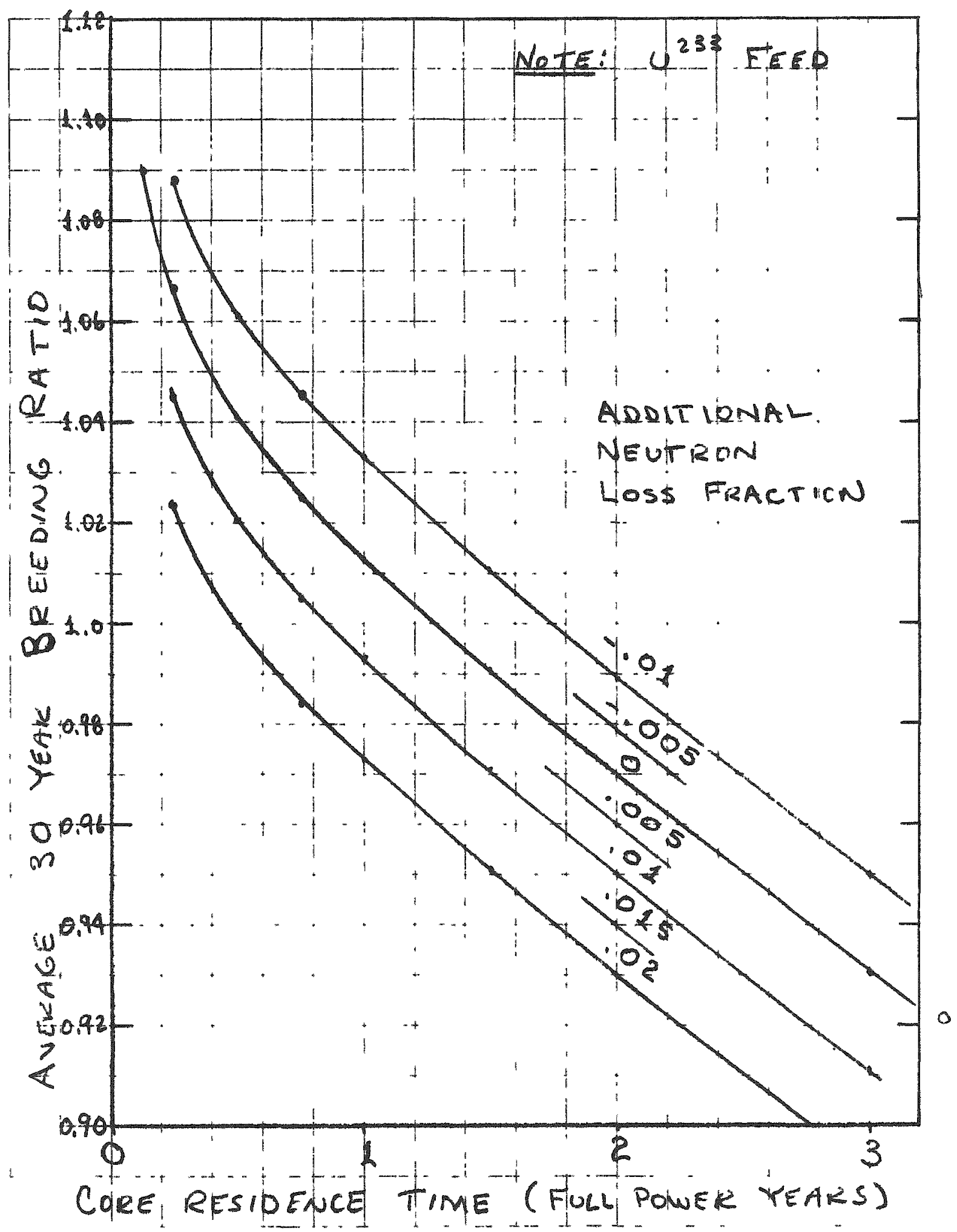

Fig. 4. Effective Breeding Ratio 


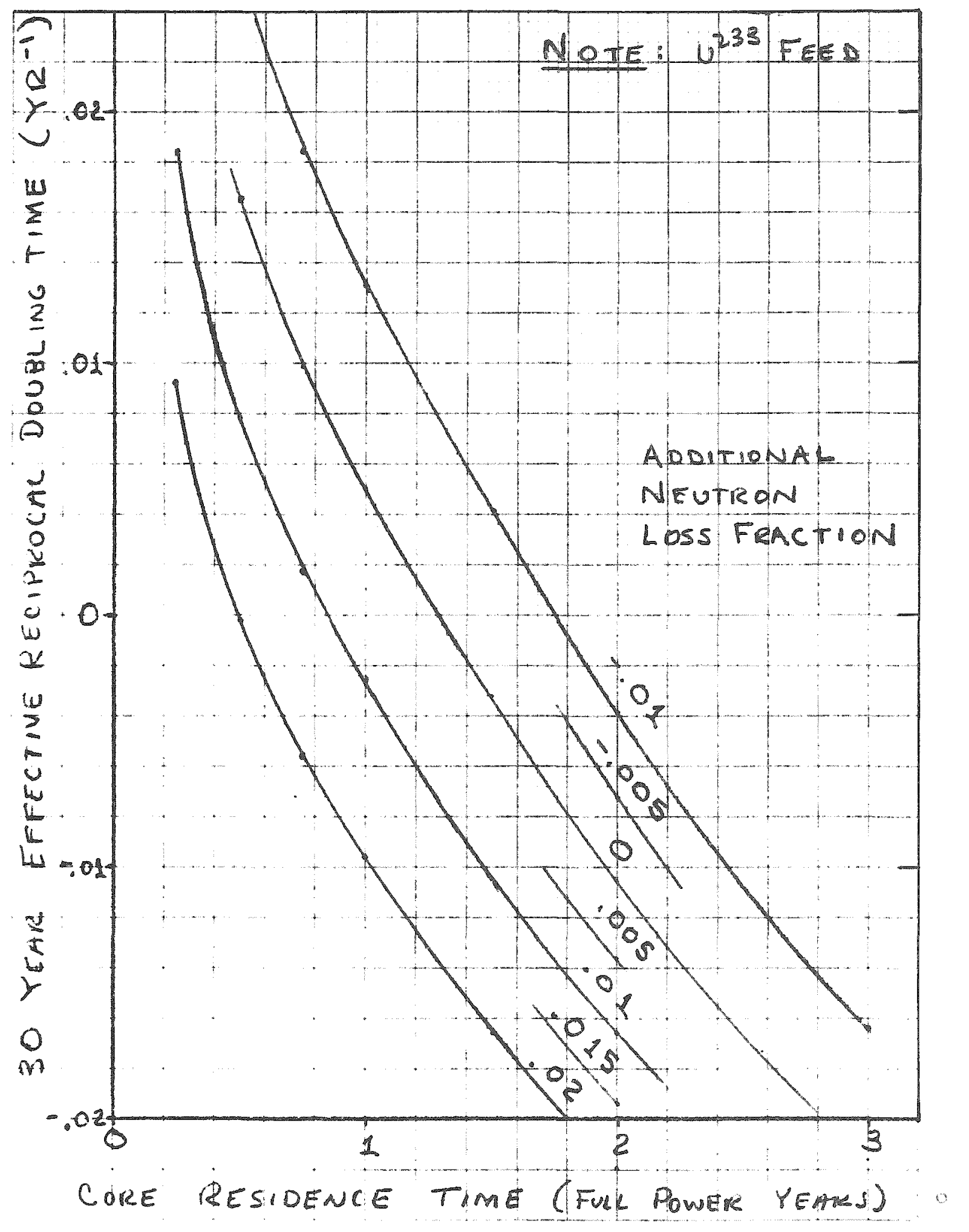

Fig. 5. Effective Reciprocal Doubling Time 
The dependence of the effective characteristics on power level were estimated. Results for thixty year historles with $\mathrm{U}^{23}$ feed are shown below for the idealized conditions:

\begin{tabular}{|c|c|c|c|c|c|c|}
\hline $\begin{array}{l}\text { Residence } \\
\text { Time } \\
\text { (ful1 power } \\
\text { yrs) }\end{array}$ & $\begin{array}{l}\text { Power } \\
\text { Leve1 } \\
\left(w_{\text {th }} / \mathrm{cc}\right)\end{array}$ & $\begin{array}{l}\text { Exposure } \\
\left(\mathrm{MWh}_{\mathrm{th}}^{-\mathrm{D} / \mathrm{Mgm} \mathrm{Th})}\right.\end{array}$ & $\begin{array}{c}\text { Total } \\
\text { F1ss11e } \\
\text { Feed } \\
(\mathrm{Kgn/} \\
\mathrm{M}^{-\mathrm{yr})}\end{array}$ & $\begin{array}{c}\text { Breeding } \\
\text { Ratio }\end{array}$ & $\begin{array}{l}\text { Doubling } \\
\text { TIme } \\
\text { (yx) }\end{array}$ & $\begin{array}{c}\operatorname{Cos} t \\
(m i 1 / \\
K e^{-h x)}\end{array}$ \\
\hline
\end{tabular}

No Delay in Recycle

$\begin{array}{rcrrrrr}1 & 2.5 & 4,740 & 5.28 & 1.100 & 53.5 & 13.14 \\ 1 & 3.75 & 7,110 & 3.68 & 1.068 & 57.1 & 9.03 \\ 1 & 5.0 & 9.480 & 3.10 & 1.039 & 79.5 & 7.01 \\ 1 & 7.5 & 14.200 & 2.38 & .989 & - & 5.07 \\ 1 & 10.0 & 19,000 & 2.04 & .944 & - & 4.19 \\ 2 & 2.5 & 9.480 & 2.71 & 1.080 & 69.3 & 7.75 \\ 2 & 3.75 & 14.200 & 2.01 & 1.039 & 104.0 & 5.47 \\ 2 & 5.0 & 19,000 & 1.67 & 1.003 & 1250.0 & 4.39 \\ 2 & 7.5 & 28,400 & 1.36 & .937 & - & 3.43 \\ 2 & 10.0 & 37,900 & 1.25 & .877 & - & 3.06\end{array}$

One Year Recycle Delay

$\begin{array}{rrrrrrr}1 & 2.5 & 4.740 & 5.05 & 1.107 & 50.0 & 12.99 \\ 1 & 3.75 & 7.110 & 3.47 & 1.076 & 51.1 & 8.91 \\ 1 & 5.0 & 9.480 & 2.94 & 1.050 & 62.0 & 6.91 \\ 1 & 7.5 & 14,200 & 2.07 & 1.002 & 1700.0 & 4.98 \\ 1 & 10.0 & 19.000 & 1.91 & .962 & - & 4.09 \\ 2 & 2.5 & 9,480 & 2.65 & 1.083 & 66.8 & 7.69 \\ 2 & 3.75 & 19,200 & 1.96 & 1.044 & 92.7 & 5.41 \\ 2 & 5.0 & 19,000 & 1.62 & 1.009 & 375.0 & 4.34 \\ 2 & 7.5 & 28,400 & 1.31 & .948 & - & 3.38 \\ 2 & 10.0 & 37,900 & 1.19 & .895 & - & 3.01\end{array}$


Production of $\mathrm{U}^{233}$ Fuel

Shown in Fig. 6 is the dependence of conversion ratio on core residence time through thirty year reactor histories estimated for a pebble bed reactor with a C/Th of 80 , considering $U^{235}$ feed and makeup with product recycle without delay. Performance with a feed mixture of $U^{23}$ and $U^{235}$ can be estimated using this data and results shown earlier (there would be preferential absorption in $\mathrm{U}^{23}$, it having a larger cross section). Delay in recycle adjusts the time scale which reduces the conversion ratio. The need for makeup $U^{235}$ feed reduces the conversion ratio, since inadequate fuel is avallable from recycle to effect criticality, a requirement which has been accounted for. These results represent an upper limit on performance since no neutron losses were included such as to account for leakage, and recycle was not delayed.

Performance of an efficient converter plant to produce $U^{233}$ breeder fuel was estimated. The following show the dependence on core residence time of the performance and estimated product composition and fuel cost assuming particle separation is admitted and ignoring $0^{235}$ recovery from the primary particles:

\begin{tabular}{|c|c|c|c|c|c|c|c|}
\hline $\begin{array}{l}\text { Residence } \\
\text { Time at } \\
\text { Full Power } \\
\text { (yr) }\end{array}$ & $\begin{array}{l}\text { Conversion } \\
\text { Ratio }\end{array}$ & $\begin{array}{l}\text { Fissile } \\
\text { Balance } \\
\text { (Kon feed } \\
\text { per Kgm } \\
\text { Product) }\end{array}$ & $\begin{array}{c}\text { Real Time to } \\
\text { Reproduce } \\
\text { Initial Fuel } \\
\text { (yr) }\end{array}$ & $\begin{array}{l}\text { Pro } \\
\frac{C}{U^{233}}\end{array}$ & $\begin{array}{l}\text { ct Com } \\
\frac{\text { orn fra }}{U^{234}}\end{array}$ & $\begin{array}{l}\text { sition } \\
\text { ion) } \\
U^{235}\end{array}$ & $\begin{array}{l}\text { Fuel } \\
\text { Cost } \\
\text { (mils/ } \\
\mathrm{KW}_{e^{-h x} \text { ) }}\end{array}$ \\
\hline 0.5 & .779 & 9.41 & 5.51 & .974 & .025 & .001 & 11.90 \\
\hline 1.0 & .769 & 5.35 & 6.50 & .960 & .038 & .002 & 6.98 \\
\hline 2.0 & .753 & 3.43 & 8.73 & .935 & .058 & .007 & 4.62 \\
\hline 4.0 & .712 & 2.71 & 14.26 & .887 & .093 & .020 & 3.64 \\
\hline
\end{tabular}

It is assumed here that clean separation of the product $\left(U^{23}\right.$ plus exposure products) would be possible, as by particle identification. 


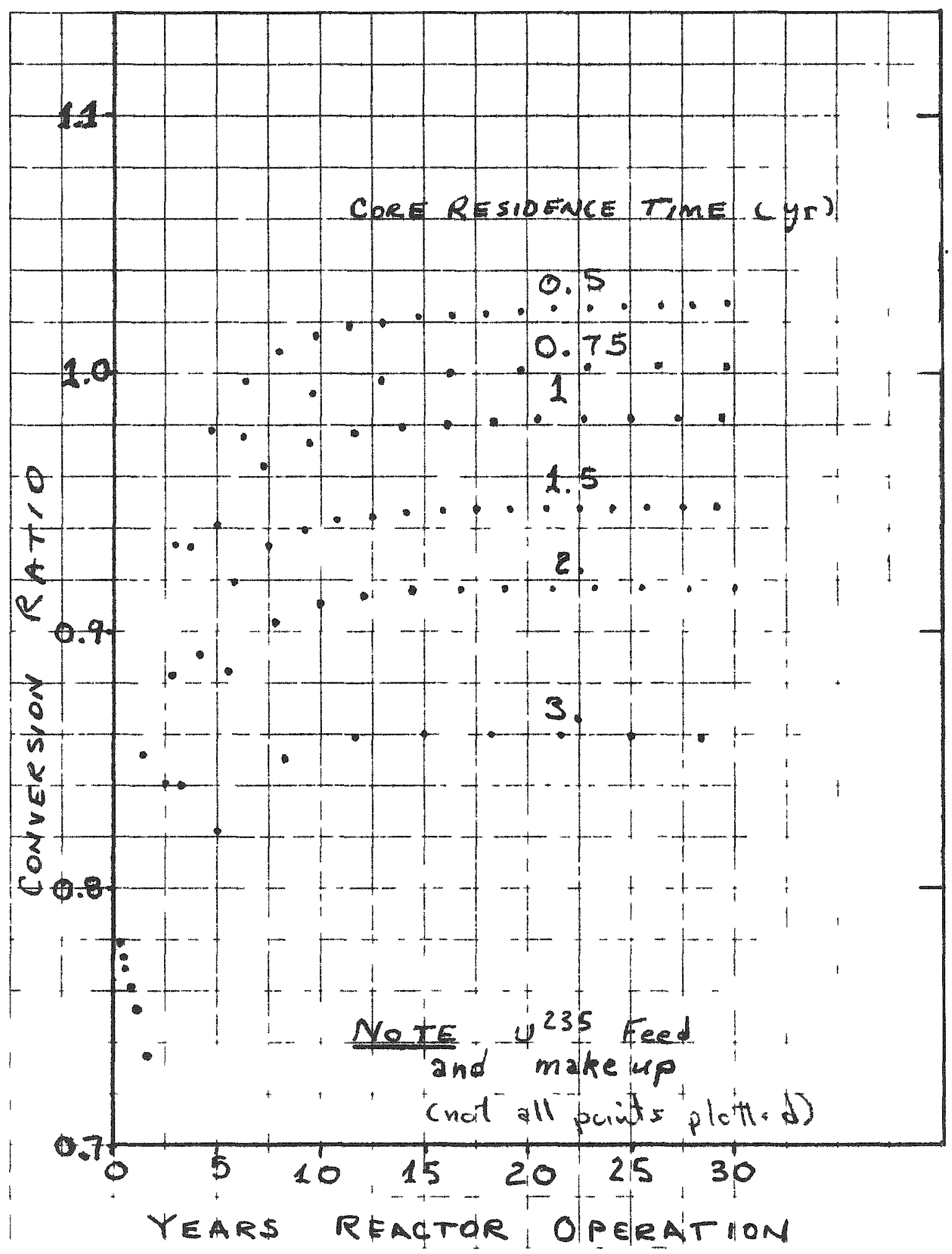

Fig. 6. Conversion Ratio with Product Recycle 
Fissile mass balances and ore consumption (excludes inventory) follow:

\begin{tabular}{|c|c|c|c|c|c|c|c|}
\hline \multirow{3}{*}{$\begin{array}{l}\text { Residence } \\
\text { Time (yr) }\end{array}$} & \multicolumn{3}{|c|}{ Primary Fuel (gm/Kw $\mathrm{e}^{-\mathrm{yr})}$} & \multirow{3}{*}{$\begin{array}{c}\text { Fissile } \\
\text { Product } \\
\left(\mathrm{gm} / \mathrm{KW}_{\mathrm{W}} \mathrm{e}^{-\mathrm{yr})}\right.\end{array}$} & \multirow{2}{*}{\multicolumn{2}{|c|}{$\begin{array}{r}\text { Ore Requirement } \\
\text { Product) }\end{array}$}} & \multirow[t]{2}{*}{ ( $\mathrm{kgm} / \mathrm{grt}$} \\
\hline & $\overline{0^{235}}$ & & 68 & & & & \\
\hline & Feed & $\overline{U^{235}}$ & $\mathrm{v}^{23}$ & & $\begin{array}{c}\text { No } \\
\text { Credit } \\
\end{array}$ & $\begin{array}{c}U^{235}-U^{236} \\
\text { Credit }\end{array}$ & $\begin{array}{l}\text { Ful1 } 0^{235} \\
\text { Credit }\end{array}$ \\
\hline 0.5 & 8.59 & 7.40 & 0.27 & .913 & 2.00 & .34 & .27 \\
\hline 1.0 & 4.40 & 3.29 & 0.25 & .823 & 1.13 & .35 & .28 \\
\hline 2. & 2.31 & 1.33 & 0.22 & .675 & .73 & .38 & .30 \\
\hline 4. & 1.35 & 0.49 & 0.17 & .499 & .58 & .44 & .37 \\
\hline
\end{tabular}

As indicated above, it is possible to generate $U^{23}$ with $U^{235}$ feed. However, considerable time elapse is involved, and reducing this by decreasing the residence time, which reduces $U^{233}$ consumption, would incur a severe cost penalty.

More realistic data is obtained by allowing for losses not accounted for in a point mode1. Results with inclusion of a 0.015 fraction loss for $U^{235}$ feed without recycle which are representative for an advanced pebble bed converter with low $\mathrm{C} / \mathrm{Th}$ are shown below:

\begin{tabular}{|c|c|c|c|c|c|c|}
\hline $\begin{array}{c}\text { Residence } \\
\text { Time at } \\
\text { Ful1 Power } \\
\text { (yr) }\end{array}$ & $\begin{array}{l}\text { Conversion } \\
\text { Ratio }\end{array}$ & $\begin{array}{l}\mathrm{U}^{235} \text { Feed } \\
\left(\mathrm{gm} / \mathrm{Kw}^{-\mathrm{yr}}\right)\end{array}$ & $\begin{array}{l}\text { Real Time } \\
\text { To Reproduce } \\
\text { Flssile } \\
\text { Loading } \\
\text { (yr) }\end{array}$ & $\begin{array}{l}\text { Atom } \\
\text { Fraction } \\
\mathrm{U}^{23} 3 \text { in } \\
\text { Product }\end{array}$ & 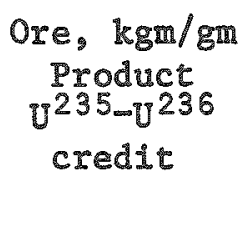 & $\begin{array}{l}\text { Fue } \\
\text { Cost } \\
\text { (mils/ } \\
\left.\mathbb{K W}_{e} e^{-h r}\right)\end{array}$ \\
\hline $\begin{array}{l}1.0 \\
2.0 \\
3.0 \\
4.0\end{array}$ & $\begin{array}{l}.737 \\
.719 \\
.699 \\
.676\end{array}$ & $\begin{array}{l}4.64 \\
2.36 \\
1.62 \\
1.28\end{array}$ & $\begin{array}{r}6.71 \\
8.55 \\
10.89 \\
13.85\end{array}$ & $\begin{array}{l}.965 \\
.944 \\
.926 \\
.910\end{array}$ & $\begin{array}{l}.37 \\
.40 \\
.44 \\
.48\end{array}$ & $\begin{array}{l}7.410 \\
4.919 \\
4.281 \\
4.100\end{array}$ \\
\hline
\end{tabular}

The value of $U^{23}$ so generated is not simple to establish. Reducing the residence time from 4 years to 1 year to increase the $U^{23}$ production has the apparent effect of adding $\$ 37 /$ gm to the product cost, relative to the assumed value of $\$ 35 / \mathrm{gm}$, apparently prohibitive.

Performance of a plant using its own product is shown in Fig. 7 with recycle delayed one year, 0.015 supplemental loss fraction, and low $\mathrm{C} / \mathrm{Th}$. 


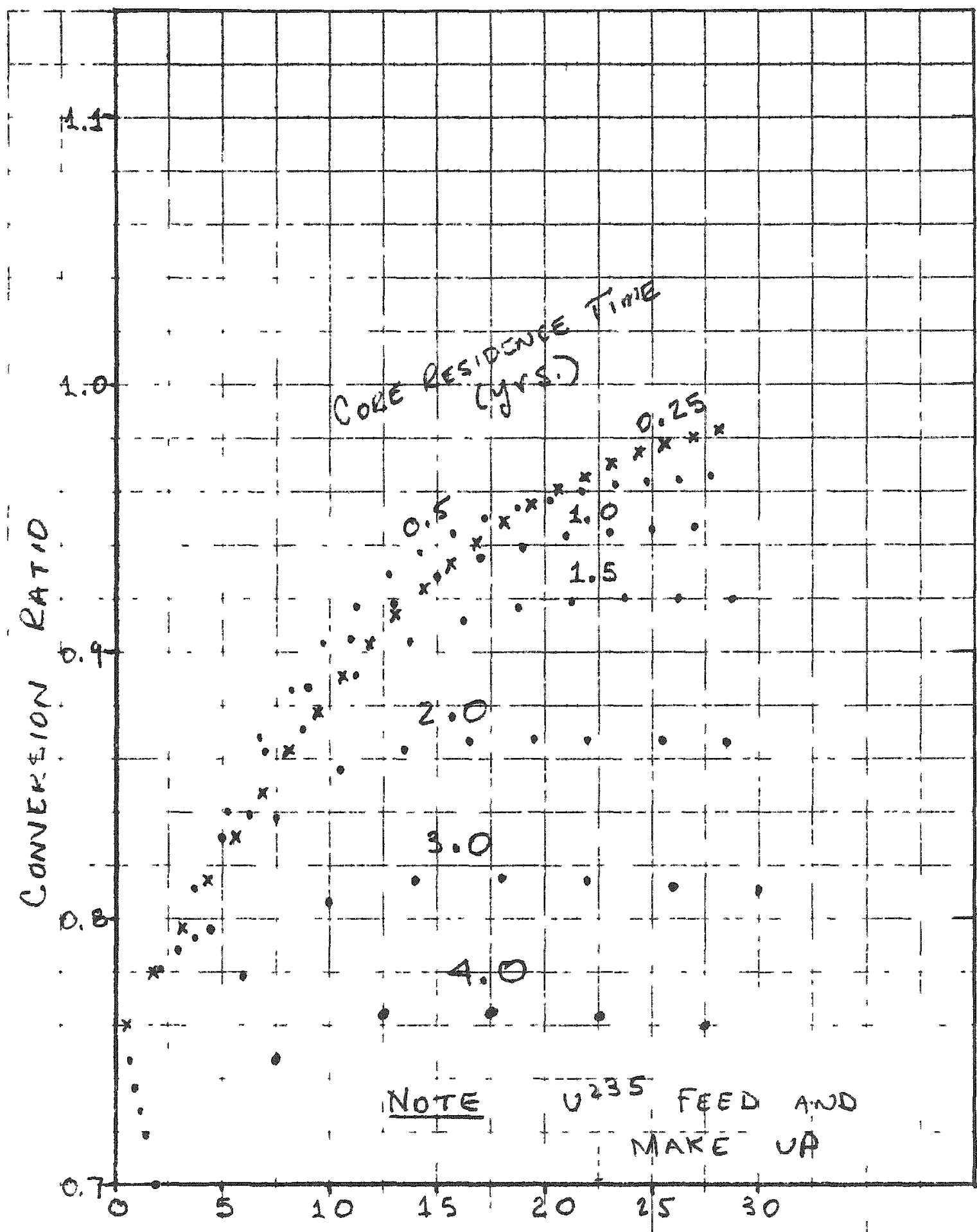

yeARS REACTOR OPERATION',

Fig. 7. Performance with $U^{235}$ Feed, Product Recycle 
Partial refueling of a reactor core appears economically feasible for reactor concepts in which the reactivity excess over the exposure period between fuelings must be compensated for with control rods. Shown below are summaries of the historles for such a reactor concept with a high carbon to thorium ratio and one cycle delay in recycle using $U^{235}$ feed:

\begin{tabular}{|c|c|c|c|c|c|c|}
\hline \multirow{2}{*}{$\begin{array}{l}\text { Residence } \\
\text { Time at } \\
\text { Ful1 Power } \\
\text { (yr) }\end{array}$} & \multirow{2}{*}{$\begin{array}{l}\text { Fraction } \\
\text { Reactor } \\
\text { Refueled }\end{array}$} & \multicolumn{2}{|c|}{ Fissile Data } & \multirow{2}{*}{$\begin{array}{l}\text { Effective } \\
\text { Conversion } \\
\text { Ratio }\end{array}$} & \multirow{2}{*}{$\begin{array}{l}\text { Ore } \\
\mathrm{Kgm} / \mathrm{KW} \text {-yr } \\
\text { Requirement } \\
\text { (No Credit) }\end{array}$} & \multirow{2}{*}{$\begin{array}{c}\text { Fuel } \\
\text { Cost } \\
(m i 1 / \\
\mathrm{KW}_{\mathrm{w}} \mathrm{e}^{-\mathrm{hr})} \\
\end{array}$} \\
\hline & & $\begin{array}{c}\text { Feed Rate } \\
\left(\mathrm{gm} / \mathrm{Kw} \mathrm{e}^{-\mathrm{yr})}\right.\end{array}$ & $\begin{array}{c}\text { Loading } \\
\left(\mathrm{Kgm} / \mathrm{Mw}_{\mathrm{e}}\right)\end{array}$ & & & \\
\hline 3. & $1 / 3$ & .986 & 1.866 & .626 & .136 & 2.582 \\
\hline 2. & $1 / 4$ & 1.021 & 1.528 & .762 & .109 & 2.428 \\
\hline 3. & $1 / 4$ & .933 & 1.826 & .664 & .124 & 2.423 \\
\hline 4. & $1 / 4$ & .934 & 2.102 & .579 & .143 & 2.575 \\
\hline 3. & $1 / 6$ & .881 & 1.755 & .702 & .113 & 2.267 \\
\hline 2. & $1 / 8$ & .963 & 1.475 & .799 & .095 & 2.268 \\
\hline 3 & $1 / 8$ & .855 & 1.728 & .721 & .107 & 2.191 \\
\hline 4. & $1 / 8$ & .840 & 2.005 & .652 & .121 & 2.274 \\
\hline 3. & $1 / 12$ & .829 & 1.673 & .739 & .101 & 2.115 \\
\hline
\end{tabular}

$A U^{23}$ product may be produced by a reactor partially refueled. Results are shown below for regeneration of the fissile loading in such a reactor (without recycle of the $\mathrm{U}^{23}$ product) at quasi-equilibrium:

\begin{tabular}{|c|c|c|c|c|c|c|c|}
\hline $\begin{array}{l}\text { Residence } \\
\text { Time at } \\
\text { Fu11 Power } \\
\text { (yx) }\end{array}$ & $\begin{array}{l}\text { Fraction } \\
\text { Reactor } \\
\text { Refueled }\end{array}$ & $\begin{array}{c}\text { Conversion } \\
\text { Ratio }\end{array}$ & $\begin{array}{c}\mathrm{U}^{235} \\
\text { Feed } \\
(\mathrm{gm} / \\
\mathrm{Kw}_{\mathrm{e}} \mathrm{e}^{-\mathrm{yr})}\end{array}$ & $\begin{array}{l}\text { Real Time } \\
\text { To Reproduce } \\
\text { Initial } \\
\text { Fue1 (yx) }\end{array}$ & $\begin{array}{l}\quad \text { Atom } \\
\text { Fraction } \\
\mathrm{U}^{23} \text { in } \\
\text { Product }\end{array}$ & $\begin{array}{l}\text { Ore } \\
\text { Kgm/gm } \\
\text { Product } \\
\text { Credit) }\end{array}$ & 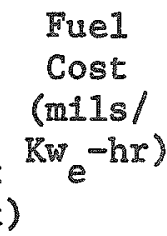 \\
\hline $\begin{array}{l}3 . \\
2 . \\
3 . \\
4 . \\
3 . \\
2 . \\
3 . \\
4 . \\
3 .\end{array}$ & $\begin{array}{l}1 / 3 \\
1 / 4 \\
1 / 4 \\
1 / 4 \\
1 / 6 \\
1 / 8 \\
1 / 8 \\
1 / 8 \\
1 / 12\end{array}$ & $\begin{array}{l}.679 \\
.740 \\
.688 \\
.637 \\
.648 \\
.750 \\
.704 \\
.658 \\
.709\end{array}$ & $\begin{array}{r}.976 \\
1.049 \\
.918 \\
.889 \\
.870 \\
.994 \\
.846 \\
.796 \\
.820\end{array}$ & $\begin{array}{r}9.75 \\
5.30 \\
9.15 \\
13.01 \\
8.65 \\
4.99 \\
8.41 \\
12.98 \\
8.15\end{array}$ & $\begin{array}{l}.87 \\
.89 \\
.87 \\
.85 \\
.86 \\
.88 \\
.86 \\
.84 \\
.85\end{array}$ & $\begin{array}{l}.612 \\
.499 \\
.574 \\
.680 \\
.543 \\
.470 \\
.528 \\
.611 \\
.511\end{array}$ & $\begin{array}{l}2.232 \\
2.031 \\
2.041 \\
2.118 \\
1.861 \\
1.840 \\
1.775 \\
1.795 \\
1.692\end{array}$ \\
\hline
\end{tabular}

More sophisticated analysis is possible. The delay in fuel production in In the early life amounts to about half the residence time, and account for the early history increases the fuel cost of energy produced and the ore commitment. Ore is also committed for plant inventory. 
Effect of Out-of-Core Hold Up on Fission Product Poison

The ORIGEN code ${ }^{7}$ was used to study the effect of out-of-core hold up on fission product poison. Typically cases were run with and without hold up. In these calculations, 100 actinides were treated and 400 fission product nuclides. Representative values of the fraction of total neutron absorptions are shown below for the situation considered $\left(U^{233}, \mathrm{Th}^{232}\right.$ initially, fixed f1ux), 36 days in-core, no out-of-core and 360 days out-of-core:

\begin{tabular}{cc|c|c|c}
\multicolumn{1}{c}{$\begin{array}{c}\text { Exposure } \\
\text { (Days) }\end{array}$} & $\begin{array}{c}\text { Out-of- } \\
\text { Core }\end{array}$ & $\begin{array}{c}\text { Start } \\
\text { Exposure }\end{array}$ & $\begin{array}{c}\text { Mid } \\
\text { Exposure }\end{array}$ & $\begin{array}{c}\text { End } \\
\text { Exposure }\end{array}$ \\
\hline 36 & .02015 & 0 & .01846 & .02034 \\
72 & .02327 & .00674 & .02231 & .02368 \\
108 & .02633 & .00983 & .02519 & .02652 \\
144 & .02928 & .01251 & .02778 & .02910 \\
180 & .03209 & .01497 & .03018 & .03149 \\
216 & .03476 & .01729 & .03245 & .03375 \\
252 & .03731 & .01950 & .03461 & .03590 \\
288 & .03978 & .02162 & .03669 & .03797 \\
324 & .09213 & .02367 & .03871 & .03997 \\
360 & .04441 & .02568 & .04067 & .04193 \\
\hline
\end{tabular}

A simple linear integration of this data indicates an average for a one year exposure of 0.0311 fraction absorptions in fission products compared with 0.0272 for the year-out-of-core hold up case, a reduction of 12 percent, worth about 0.009 in the effective breeding ratio. (The composition considered was deliberately selected as low enrichment, not core average, 2 percent $\mathrm{U}^{23}$ In $\mathrm{Th}^{232 .)}$ 
A number of problems were solved to test the reliability of the results via perturbation. A sumary of results is show below to assess the effect of hold up on the fission product poison level:

\begin{tabular}{|c|c|c|c|c|c|c|c|}
\hline \multirow{4}{*}{$\frac{\text { Exposure }}{\text { Interva1 }}$} & \multirow{4}{*}{$\frac{\text { (Days) }}{\text { Total }}$} & \multirow{4}{*}{$\begin{array}{c}\text { Out-of-Core } \\
\text { Hold Up } \\
\text { (Days) }\end{array}$} & \multirow{2}{*}{\multicolumn{4}{|c|}{$\begin{array}{c}\text { Fraction Neutron Absorptions } \\
\text { In Fission products }\end{array}$}} & \multirow{4}{*}{$\begin{array}{l}\text { Implied } \\
\text { Gain In } \\
\text { Breeding } \\
\text { Ratio by } \\
\text { Fission } \\
\text { Product } \\
\text { Hold Up }\end{array}$} \\
\hline & & & & & & & \\
\hline & & & End of & History & Integrated & Average & \\
\hline & & & $\begin{array}{l}\text { No } \\
\text { Hold up }\end{array}$ & $\begin{array}{c}\text { With } \\
\text { Hold Up }\end{array}$ & $\begin{array}{l}\text { No } \\
\text { Hold Up }\end{array}$ & $\begin{array}{l}\text { With } \\
\text { Hold Up }\end{array}$ & \\
\hline 36 & 360 & 360 & .0444 & .0419 & .0311 & .0272 & 0.009 \\
\hline 72 & 720 & 360 & .0640 & .0608 & .0430 & .0396 & 0.008 \\
\hline 72 & 720 & 180 & .0640 & .0620 & .0430 & .0404 & 0.006 \\
\hline 72 & 720 & 72 & .0640 & .0630 & .0430 & .0411 & 0.004 \\
\hline
\end{tabular}

A primary contribution to the reduction in fission product losses from external hold up 1 s reduced $\mathrm{Xe}^{135}$ absorption. The above exposures result In approximately 270 and $540 \mathrm{Kw}_{t h}-\mathrm{D} / \mathrm{gm} \mathrm{U}^{233}$ energy generation $\left(2.72 \mathrm{w}_{\mathrm{th}} / \mathrm{cc}\right)$ which have associated fission product poisoning iractions at end of exposure of 0.0444 and 0.0640 respectively.

This data allows a rough estimate to be made in the effect on breedIng ratio of neutron loss to the fission products. The higher exposure above is equivalent to about 313 days at $6.25 \mathrm{w}_{\mathrm{th}} / \mathrm{cc}$. Selected results are displayed below for $\frac{\Delta C}{C}$ and the rate of change with change in exposure time:

Mode1 $\frac{\Delta C}{C} \quad \frac{\Delta C}{C \Delta T}\left(y x^{-1}\right)$

The ORIGEN results $0.096 \quad 0.062$

Simple point model results (shown earlier)

0.093

0.051

One-dimensional results (shown later)

0.071 0.055 
The fission product nuclides which play a dominating role in the absorption of neutrons are listed below in order of decreasing importance after a long exposure perlod:

\begin{tabular}{l|c|c|c|c|} 
NUCLIDE & \multicolumn{2}{|c|}{ WITH HOLD UP } & \multicolumn{2}{c}{ WITHOUT HOLD UP } \\
\cline { 2 - 4 } & $\begin{array}{c}\text { Order of } \\
\text { Importance }\end{array}$ & $\begin{array}{c}\text { Fraction } \\
\text { Neutron Absorptions }\end{array}$ & $\begin{array}{c}\text { Order of } \\
\text { Importance }\end{array}$ & $\begin{array}{c}\text { Fraction } \\
\text { Neutron Absorptions }\end{array}$ \\
\hline
\end{tabular}

\begin{tabular}{|c|c|c|c|c|}
\hline & & & & \\
\hline $\mathrm{Xe}^{135}$ & 1 & .0146 & 1 & .0145 \\
\hline $\mathrm{Nd}^{143}$ & 2 & .00550 & 4 & .00537 \\
\hline $\mathrm{Cs}^{133}$ & 3 & .00524 & 5 & .00513 \\
\hline $\mathrm{Xe}_{149}^{131}$ & 4 & .00516 & 6 & .00503 \\
\hline $\mathrm{Sm}^{249}$ & 5 & .00467 & 2 & .00558 \\
\hline $\mathrm{Pm}^{247}$ & 6 & .00364 & 3 & .00537 \\
\hline $\mathrm{Rh}^{2} 3$ & 7 & .00319 & 7 & .00310 \\
\hline $\mathrm{Sm}^{352}$ & 8 & .00193 & 9 & .00192 \\
\hline $\mathrm{Stg}^{151}$ & 9 & .00186 & 10 & .00192 \\
\hline $\mathrm{Nd}^{145}$ & 10 & .00155 & 11 & .00151 \\
\hline $\mathrm{Mo}^{25}$ & 11 & .00134 & .13 & .00116 \\
\hline $\mathrm{Pm}^{2404}$ & 12 & .00129 & 8 & .00197 \\
\hline $\mathrm{Tc}^{93}$ & 13 & .00119 & 12 & .00116 \\
\hline $\mathrm{Sm}^{248}$ & 14 & .00113 & 25 & .000365 \\
\hline $\mathrm{Eu}^{253}$ & 15 & .00112 & 14 & .00110 \\
\hline $\mathbb{R}^{83}$ & 16 & .00102 & 15 & .000997 \\
\hline $\mathrm{Sm}^{2} 50$ & 17 & .000714 & 16 & .000824 \\
\hline $\mathrm{Ru}^{101}$ & 18 & .000486 & 18 & .000474 \\
\hline $\mathrm{Pm}^{14}$ & 19 & .000452 & 17 & .000675 \\
\hline $\mathrm{Eu}^{154}$ & 20 & .000451 & 20 & .000465 \\
\hline $\mathrm{Rh}^{105}$ & 21 & .000444 & 21 & .000442 \\
\hline $\mathrm{Cs}^{135}$ & 22 & .000442 & 22 & .000428 \\
\hline $\operatorname{Pr}^{141}$ & 23 & .000439 & 23 & .000421 \\
\hline $\operatorname{En}^{155}$ & 24 & .000434 & 19 & .000470 \\
\hline $2 r^{93}$ & 25 & .000422 & 24 & .000412 \\
\hline$I^{128}$ & 26 & .000354 & 26 & .000345 \\
\hline $\mathrm{La}^{132}$ & 27 & .000298 & 27 & .000291 \\
\hline $\mathrm{Nd}^{146}$ & 28 & .000228 & 29 & .000223 \\
\hline$I^{127}$ & 29 & .000214 & 31 & .000203 \\
\hline $\mathrm{Mo}^{97}$ & 30 & .000210 & 30 & .000205 \\
\hline $\mathrm{Cs}^{134}$ & 31 & .000187 & 28 & .000287 \\
\hline Sum & & .0602 & & .0623 \\
\hline
\end{tabular}

The sma11 difference in the results and the dominant role played by essentially the same nuclides may be noted. Involved chain routes (couplings) complicate the selection of a simplified representation which will be reliable. 
The more important actinides are shown below with absorption fractions ordered by importance in neutron absorption ( $0^{23}$ fuel):

Nuc1ides

$\operatorname{Th} 232$

$\mathrm{J} 233$

$\mathrm{U}^{234}$

$\mathrm{Pa}^{233}$

$\mathrm{U}^{235}$

$\mathrm{Pa}^{231}$

$\mathrm{U}^{236}$

$u^{232}$

$\operatorname{Th}^{233}$

$\mathrm{Np} 237$

Th 230

$\mathrm{Pu} 238$

$\mathrm{Pu}^{239}$

$\operatorname{Th}^{229}$

Np 238

$\mathrm{Pu}_{240}$

$\mathrm{Th}^{228}$

$\mathrm{Pu}^{241}$

I 237

$\mathrm{Pu} 242$

Am 241

$\operatorname{Am}^{24} 3$

$\mathrm{Ra}^{224}$

$\mathrm{Pu}^{236}$

$\mathrm{Cm}^{244}$

$\mathrm{Cm}^{245}$

$\mathrm{Am}^{24} 2$

$\mathrm{Cm} 242$

$\mathrm{Cm}^{243}$

$\mathrm{Am}^{244}$

$\mathrm{Np} 236$

Pu 243

$\mathrm{Cm}^{246}$

\section{Fraction Absorptions}

.468

.428

.0232

.0108

.00583

.000164

$7.93-5$

3. $65-5$

$1.99-5$

1. $16-5$

6.99-6

1. 17-6

$3.28-7$

$8.30-8$

5. $98-8$

5.27-8

4. $33-8$

1. $25-8$

7. 19-9

2.73-10

5.02-11

2.51-11

2. 22-11

3. 37- 12

1. $19-12$

8. 93-13

1. 52-13

$1.27-13$

$7.75-14$

1.09-14

$1.64-15$

1.01-15

5. 47-16

One DImensional Survey Results

The reactor core is described quite well with a simple one-dimensional traverse (unless residence tlme depends on radial location or a radial blanket makes a large contribution). For the reference calculations, 20 axial core zones were treated, plus 3 more with the blanket represented, 
In the continuous feed, once-through exposure model. A direct iterative approach was used to adjust the amount of fuel feed to the reactor, and successive neutronics critlcality search, exposure calculations effected near critical condtions.

The calculations were done for $6 \mathrm{~cm}$ diameter primary (or single) pellets and $1 \mathrm{~cm}$ diameter fertile pellets. There is considerable uncertalnty regarding the calculation of resonance shielding, so the results are appropriate to some pellet size and some distribution of the carbon and thorlum not well 1dentified. Initlal calculatlons were done with pure $0^{23}$ feed in the primary pellets, no fissile material in the fert1le pellets, and also pure $0^{23}$ in the fertlle pellets to examine performance under this ideal feed condition.

Results are shown in Table 1 for selected cases Involving a 2 year residence time for single pebbles and a 1 year residence time for the primary pebbles, 0.1 year residence time for the fertile pebbles with a low ratio of Th in the fertile pebbles to that in the primary pebbles of 1:3. Average power density for the reactor was $2.5 \mathrm{~W}_{\mathrm{e}} / \mathrm{cc}(6.25$ thermal) and mass balances are for a 1,500 Mw plant. The core had volume of 6 If $10^{\circ} \mathrm{cc}$ and was $460 \mathrm{~cm}$ high. The $\mathrm{C} / \mathrm{Th}$ ratio was about 80 (slightly higher for the case with a blanket). Note from the neutron balance that the "other losses", which include a radial buckling loss, were sma11, which assumes relatively effective neutron reflection at the top (entrance), an aspect subject to further analysis.

The fisslle mass balance and other data assume full $\mathrm{U}^{23}$ recovery (from $\mathrm{Pa}^{23}$ ) and no processing loss. 
Table 1. One Dimensional Results (No Recycle)

\begin{tabular}{|c|c|c|c|c|}
\hline Case & Blala & B1a2a & B1b2a & $\mathrm{B} 1 \mathrm{~b} 2 \mathrm{~b}$ \\
\hline Axial Blanket & No & No & No & Yes \\
\hline \multicolumn{5}{|c|}{ Core Residence Time (yr. full power, excludes residence in blanket) } \\
\hline Primary pebbles & 2.0 & 1.0 & 1.0 & 1.0 \\
\hline Fertile pebbles & - & 0.1 & 0.1 & 0.1 \\
\hline Neutron Energy Groups & 2 & 2 & 8 & 8 \\
\hline Conversion Ratio & 0.937 & 1.017 & 1.016 & 1.023 \\
\hline $\begin{array}{l}\text { Reciprocal Doubling } \\
\text { Time }\left(\mathrm{yr}^{-1}\right)\end{array}$ & -0.0354 & .0057 & .0050 & .0078 \\
\hline \multicolumn{5}{|c|}{ Fissile Mass Balance ( $\mathrm{kgm} / \mathrm{day}$ at full power) } \\
\hline U233 Feed & 5.477 & 18.90 & 19.81 & 18.73 \\
\hline Discharge & 5.183 & 18.98 & 19.89 & 18.84 \\
\hline \multicolumn{5}{|c|}{ Feed Enrichment $\mathrm{U}^{233} / \mathrm{Th}_{\mathrm{U}} \mathrm{U}^{233}$ ) } \\
\hline Primary Balls & .03361 & .04995 & .05337 & .04931 \\
\hline Fertile Balls & - & .00794 & .00794 & .00794 \\
\hline Fissile Inventory (Kgm) & 3,876 & 4,569 & 4,900 & 4,543 \\
\hline \multicolumn{5}{|c|}{ Peak Radial Average Power Density } \\
\hline$\left(W_{t h} / c c\right)$ & 12.42 & 11.96 & 11.70 & 12.06 \\
\hline \multicolumn{5}{|l|}{ Neutron Loss Accounting } \\
\hline $\operatorname{Th}^{232}$ & .42794 & .46988 & .47101 & .47235 \\
\hline $\mathrm{Pa}^{233}$ & .01290 & .00880 & .00842 & .00903 \\
\hline$u^{233}$ & .45186 & .45572 & .45610 & .45469 \\
\hline$U^{234}$ & .01222 & .00516 & .00500 & .00505 \\
\hline$u^{235}$ & .00252 & .00047 & .00042 & .00058 \\
\hline$v^{236}$ & .00003 & .0 & .0 & .0 \\
\hline $\mathrm{Xe}^{135}$ & .01453 & .01297 & .01217 & .01292 \\
\hline $\mathrm{Na}^{143}$ & .00326 & .00133 & .00121 & .00132 \\
\hline $\mathrm{Pm}^{147}$ & .00323 & .00176 & .00171 & .00173 \\
\hline $\mathrm{Pm}^{148}$ & .00052 & .00027 & .00026 & .00026 \\
\hline $\mathrm{Pm}^{148 \mathrm{~m}}$ & .00116 & .00059 & .00056 & .00058 \\
\hline $\mathrm{Sm}^{149}$ & .00467 & .00366 & .00360 & .00364 \\
\hline other fp & .03574 & .01550 & .01525 & .01542 \\
\hline $\mathrm{C}$ & .00563 & .00462 & .00426 & .00491 \\
\hline Other losses & .02379 & .01927 & .02003 & .01752 \\
\hline Tota1 & 1.0 & 1.0 & 1.0 & 1.0 \\
\hline
\end{tabular}


These results indicate that an inftal conversion ratio of 0.94 is achievable with one pebble and $u^{23}$ feed with a 2 year residence time. With two pebbles, a breeding ratlo of 1.02 is achievable initially with residence times of 1 year for the primary pebbles and 0.1 year for the fertile pebbles. The eight group results indicate a slightly lower performance than the two group results ( 5 percent higher fissile feed). Undoubtedly a better fine group cross section collapae than the point model used would reduce this discrepancy, since it is caused directly by the difference in effective spectrum. St111, the two group results appear adequate for survey analysis, especlally considering the close approximation of the conversion ratio and no major discrepancy in the secondary neutron losses which include core leakage. Comparison with the point model results show a gain from the spacial flux distribution in the losses to fission products of fraction 0.10 , lower absorptions in $\mathrm{C}$ and $\mathrm{Pa}^{23}$ and higher U isotopes, but additional 0.02 fraction leakage loss, which is deemed to be low without blankets.

Case B1b2b shows the performance with a $31 \mathrm{~cm}$. axial blanket which increased the in-core thorium loading from 116 to $120 \mathrm{Mgms}$. A gain of 0.005 in the breeding ratio is realized, not all that is possible with a higher thorlum loading or thicker blanket.

Additional calculations were made which indicated that only a small decrease in the conversion ratio accompanies increases in the fertile pebble residence time or fissile contents, but the conversion ratio increases substantially as the primaxy pebble residence time is reduced.

Results from one-dimensional, eight group calculations considering $U^{233}$ feed, a high ratio of Th in the fertile pebbles to that in the primary pebbles of $3: 1$, with an axial blanket at the entrance of fertile feed pebbles, are shom in Table 2. Although a C to Th ratio of 80 was 
Table 2. Results for the Two-Ball Pebble Bed Reactor (One-Dimensional, Eight Group, Fresh U 233 Feed, Blanket)

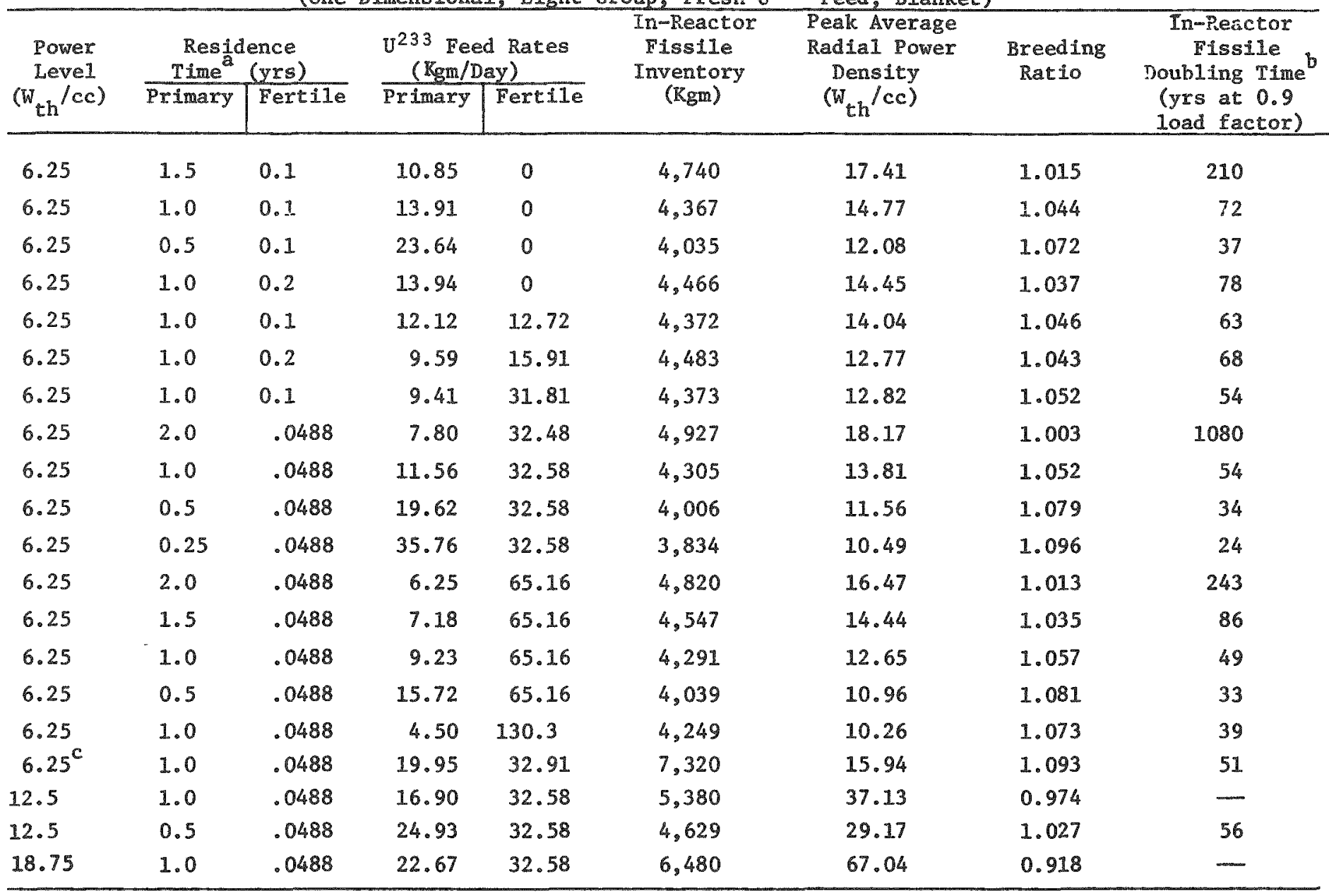

In the core proper, excludes blanket time (full power).

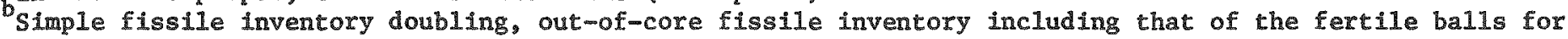
hold up not included.

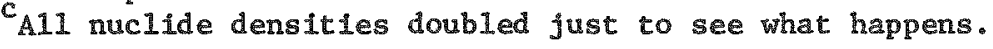


Intended and the cross sections were processed for this ratio, these cases were run with a ratio of 88 .

Problems were solved to examine the effect of recycle in the early life on performance and the results are shown in Table 3. Material from discharged primary pebbles was used as primary pebble feed, supplemented with $U^{23}$. Fertile recycle materlal was considered to be held up one year and primary material chemically processed. Note that a one-year delay in recycle would cause the tenth refueling to occur at about 20 years, or 22 years real time at a load factor of 0.9 .

Note that in the results considering recycle, the fissile inventory increases as the higher uranium isotopes, especially $U^{234}$, build up. It appears that the fertile loading should be reduced to hold down the fissile inventory, but much reduction significantly reduces the conversion ratio and Increases the doubling time. (Perhaps the guideline should be minimizing the doubling time. Here the reported results do not take into account the lower worth of $\mathrm{U}^{235}$ relative to $\mathrm{U}^{233}$ in the reactor.) These results also suggest an effect of uncertainty in the calculations.

Certain calculations were made to test reliability of the results. Shown in Table 4 are results obtalned with changes in the axial blanket thickness and a reduced number of depletion zones in the core for residence times in the core proper of 1 year primary and 0.0488 year fertile pebbles. Unfortunately the original mesh and zone arrangement $(20$ zones in the core) did not lend itself to consistent reduction in the number of zones in the core. However, even halving the number of depletion zones in the core led to only a small difference in the results. A small increase in the conversion ratio resulted from increase in the entrance blanket thickness and from adding an exit blanket. 
Table 3. Results for Recycle

\begin{tabular}{|c|c|c|c|c|c|c|c|c|c|}
\hline \multirow{3}{*}{$\begin{array}{l}\text { Recycle } \\
\text { Pass }\end{array}$} & \multirow{3}{*}{$\frac{\text { Recycle }}{\text { Primary }}$} & \multirow{3}{*}{$\frac{\text { Fraction }}{\text { Fertile }}$} & \multicolumn{4}{|c|}{ Fissile Rate Balance $(\mathrm{Ggm} / \mathrm{D})$} & \multirow{3}{*}{$\begin{array}{l}\text { In-Reactor } \\
\text { Fissile } \\
\text { Inventory } \\
\text { (Kgm) }\end{array}$} & \multirow{3}{*}{$\begin{array}{l}\text { Breeding } \\
\text { Racio }\end{array}$} & \multirow{3}{*}{$\begin{array}{l}\text { In-Reactor Fissile } \\
\text { Doubling Time } \\
\text { (yrs. at } 0.9 \text { load } \\
\text { factor) }\end{array}$} \\
\hline & & & \multicolumn{2}{|c|}{ Feed } & \multicolumn{2}{|c|}{ Discharge } & & & \\
\hline & & & $\overline{\text { Prinmary }}$ & Pertide & Primary & Tertile & & & \\
\hline 0 & 0 & 0 & 11.58 & 32.58 & 9.10 & 35.30 & 4,305 & 1.0514 & 53.57 \\
\hline 1 & 1.0 & 0 & 12.16 & 32.58 & 9.67 & 35.28 & 4,524 & 1.0516 & 55.87 \\
\hline 1 & 1.0 & 0 & 12.56 & 26.07 & 9.99 & 28.88 & 4,510 & 1.0525 & 55.82 \\
\hline 1 & 1.0 & 1.0 & 11.95 & 35.30 & 9.55 & 37.95 & 4,522 & 1.0528 & 54.72 \\
\hline 1 & 1.0 & 0.9 & 12.19 & 31.77 & 9.73 & 34.48 & 4,521 & 1.0524 & 55.48 \\
\hline 1 & 1.0 & 0.8 & 12.44 & 28.24 & 9.90 & 31.02 & 4,520 & 1.0520 & 56.24 \\
\hline 2 & 1.0 & 0.9 & 12.78 & 31.04 & 10.32 & 33.74 & 4,724 & 1.0519 & 58.11 \\
\hline 3 & 1.0 & 0.9 & 13.29 & 30.38 & 10.83 & 33.08 & 4,899 & 1.0523 & 61.72 \\
\hline 4 & 1.0 & 0.9 & 13.87 & 29.78 & 11.40 & 32.47 & 5,102 & 1.0494 & 65.64 \\
\hline 5 & 1.0 & 0.9 & 14.32 & 29.23 & 11.85 & 31.92 & 5.257 & 1.0479 & 70.00 \\
\hline 6 & 1.0 & 0.9 & 14.74 & 28.74 & 12.27 & 31.42 & 5,400 & 1.0462 & 74.66 \\
\hline 7 & 1.0 & 0.9 & 15.12 & 28.29 & 12.64 & 30.97 & 5.531 & 10444 & 79.62 \\
\hline 8 & 1.0 & 0.9 & 15.47 & 27.88 & 12.99 & 30.56 & 5,651 & 1.0426 & 84.87 \\
\hline 9 & 1.0 & 0.9 & 15.80 & 27.51 & 13.31 & 30.18 & 5.763 & 1.0406 & 90.35 \\
\hline 10 & 1.0 & 0.9 & 16.09 & 27.17 & 13.60 & 29.84 & 5,862 & 1.0391 & 98.52 \\
\hline $10 \%$ & 1.0 & 0.9 & 15.03 & 27.17 & 12.62 & 29.74 & 5,490 & 1.0339 & 104.2 \\
\hline $10 * \%$ & 1.0 & 0.9 & 14.01 & 27.17 & 11.68 & 29.63 & 5.135 & 1.0282 & 112.5 \\
\hline $10 \%$ & 1.0 & 0.9 & 12.04 & 27.17 & 9.89 & 29.39 & 4,454 & 1.0180 & 156.3 \\
\hline
\end{tabular}

$* \mathrm{Th}^{232}$ feed reduced $5 \%$ in fertile pebbles to lower fissile inventory.

*Th ${ }^{232}$ feed reduced $10 \%$ in fertlle pebbles.

*** $\mathrm{Th}^{232}$ feed reduced $20 \%$ in fertile pebbles. 
Table 4. Further Results From the One-Dimensional Mode1

\begin{tabular}{|c|c|c|c|c|c|c|c|c|c|}
\hline \multirow{3}{*}{$\begin{array}{l}\text { Depleting } \\
\text { Zones In } \\
\text { Core }\end{array}$} & \multirow{2}{*}{\multicolumn{2}{|c|}{$\begin{array}{c}\text { Axial } \\
\text { Blanket } \\
\text { Thickness }\end{array}$}} & \multirow{2}{*}{\multicolumn{2}{|c|}{$\begin{array}{l}\text { U233 Feed Rates } \\
\text { ( } \mathrm{Kgm} / \mathrm{Day}) \\
\end{array}$}} & \multirow{3}{*}{$\begin{array}{c}\text { In-Reactor } \\
\text { Fissile } \\
\text { Inventory } \\
\text { (Kgm) }\end{array}$} & \multirow{3}{*}{$\begin{array}{l}\text { Peak Average } \\
\text { Radial Power } \\
\text { Density } \\
\left(w_{t h} / c c\right)\end{array}$} & \multicolumn{2}{|c|}{$\begin{array}{l}\text { Breeding } \\
\text { Ratio }\end{array}$} & \multirow{3}{*}{$\begin{array}{c}\text { In-Reactor } \\
\text { Fissile } \\
\text { Doubling Time } \\
\text { (yrs at } 0.9 \\
\text { load factor) }\end{array}$} \\
\hline & & & & & & & \multirow{2}{*}{$\begin{array}{l}\text { Reaction } \\
\text { Rate }\end{array}$} & \multirow{2}{*}{$\begin{array}{c}\text { Mass } \\
\text { Balance }\end{array}$} & \\
\hline & Entrance & Exit & Primary & Fertile & & & & & \\
\hline 10 & 41.3 & 0 & 13.86 & 0 & 4,296 & 15.28 & 1.0550 & 1.0566 & 51.62 \\
\hline 10 & 41.3 & 0 & 11.54 & 32.58 & 4,318 & 14.17 & 1.0594 & 1.0601 & 47.83 \\
\hline 15 & 27.5 & 0 & 11.56 & 32.57 & 4,290 & 13.94 & 1.0506 & 1.0517 & 55.63 \\
\hline 20 & 31.0 & 0 & 11.58 & 32.58 & 4,305 & 13.81 & 1.0527 & 1.0514 & 53.57 \\
\hline 20 & 41.3 & 0 & 13.86 & 0 & 4,302 & 14.80 & 1.0538 & 1.0555 & 52.53 \\
\hline 20 & 41.3 & 0 & 11.55 & 32.58 & 4,325 & 13.80 & 1.0587 & 1.0580 & 48.40 \\
\hline 20 & 41.3 & 41.3 & 13.84 & 0 & 4,309 & 14.72 & 1.0556 & 1.0575 & 50.58 \\
\hline 20 & 41.3 & 41.3 & 12.67 & 16.28 & 4,373 & 14.21 & 1.0578 & 1.0598 & 49.91 \\
\hline 20 & 41.3 & 41.3 & 11.52 & 32.58 & 4,443 & 13.69 & 1.0608 & 1.0619 & 47.94 \\
\hline
\end{tabular}


The convergence properties of the calculational procedure in use are of interest. The initial nuclide concentrations were set uniform as a starting point without any attempt to supply a gradient, but the fuel concentration in an artificial zone for the primary particle feed was made somewhat larger than the value within the core as a technique found to be desirable to accelerate the convergence rate. The iterative behavior in effecting a converged solution for a problem is shown below:

\begin{tabular}{|c|c|c|c|c|c|c|}
\hline $\begin{array}{c}\text { End of } \\
\text { Iteration } \\
\text { Sweep }\end{array}$ & $\begin{array}{l}\text { Neutronics } \\
\text { Problem } \\
\text { Outer } \\
\text { Iterations }\end{array}$ & $\begin{array}{c}\mathrm{U}^{23} \text { Feed } \\
\text { Rate } \\
\text { (Kgm/day) }\end{array}$ & $\begin{array}{l}\text { In-Reactor } \\
\text { Fissile } \\
\text { Inventory } \\
\text { (Rgm) }\end{array}$ & $\begin{array}{l}\text { Peak Average } \\
\text { Radial Power } \\
\text { Density } \\
\left(w_{t h} / c c\right)\end{array}$ & $\begin{array}{l}\text { Breeding } \\
\text { Reaction } \\
\text { Rates }\end{array}$ & $\frac{\text { Ratio }}{\text { Mass }}$ \\
\hline 1 & 42 & 44.098 & 4,213 & 9.72 & 1.1700 & 0.8980 \\
\hline 2 & 40 & 42.963 & 3,892 & 16.63 & 1.0762 & 1.1167 \\
\hline 3 & 51 & 44.503 & 4,423 & 13.03 & 1.0502 & 1.0262 \\
\hline 4 & 44 & 44.062 & 4,275 & 13.78 & 1.0540 & 1.0573 \\
\hline 5 & 27 & 44.141 & 4,298 & 13.91 & 1.0530 & 1.0521 \\
\hline 6 & 29 & 44.174 & 4,311 & 13.77 & 1.0525 & 1.0503 \\
\hline 7 & 19 & 44.153 & 4,304 & 13.81 & 1.0528 & 1.0516 \\
\hline 8 & 20 & 44.158 & 4,305 & 13.82 & 1.0527 & 1.0514 \\
\hline 9 & 3 & 44,158 & 4,305 & 13.81 & 1.0527 & 1.0514 \\
\hline 10 & 2 & 44,158 & 4,305 & 13.81 & 1.0527 & 1.0514 \\
\hline
\end{tabular}

Note that the iterative process is quite stable and the procedure effective in this situation.

Under certain conditions an oscillatory behavior was found to occur, and an acceptable solution to the critical reactor problem was not obtained. The oscillation was found to be driven by a shift between two space, energy Ilux distributions associated with the successive estimates of the zone nuclide concentrations, not by the criticality search adjustments. Even when a procedure was used to simply determine the multiplication factor in 
successive solutions of the neutronics code, the oscillation between two solutions persisted. The exposure module was modified to produce a weightIng between start and end exposure nuclide concentrations. In the continwous fueling model, this option weights between successive estimates of the average nuclide concentrations. A simple average between the two was found to stabilize the process, although the rate of convergence was slow. Considering a weighting factor $W$, the weighted concentrations are given by

$$
C(W)=C(E)+W[C(E)-C(S)] \text {. }
$$

where $\mathrm{E}$ refers to end and $\mathrm{S}$ to start of exposure (successive estimates of the zone average). Results are shown below for a case:

\begin{tabular}{|c|c|c|c|c|c|c|}
\hline $\begin{array}{l}\text { Weighting Factor } \\
\text { Iteration }\end{array}$ & 0.5 & 0.3 & 0.25 & 0.2 & 0.1 & 0 \\
\hline 1 search eigenvalue* & -2.18 & -2.18 & -2.18 & -2.18 & -2.18 & -2.18 \\
\hline 2 & 0.216 & 0.290 & 0.308 & 0.326 & 0.360 & 0.393 \\
\hline$"$ & 0.167 & 0.218 & 0.228 & 0.235 & 0.239 & 0.222 \\
\hline$"$ & 0.106 & 0.060 & 0.031 & -.008 & -120 & -.250 \\
\hline$"$ & 0.073 & 0.084 & 0.102 & 0.129 & 0.193 & 0.233 \\
\hline$"$ & 0.051 & 0.023 & 0.004 & -.029 & -.166 & -.305 \\
\hline$"$ & 0.036 & 0.032 & 0.045 & 0.072 & 0.182 & 0.270 \\
\hline$k_{\text {eff }}$ & 0.995 & 0.9983 & 1.0003 & 1.0043 & $-\infty$ & 1.0529 \\
\hline 9 & 0.9895 & 0.9959 & 0.9972 & 0.9986 & 0.9967 & 0.9762 \\
\hline $\begin{array}{l}\text { End Conversion Ratio } \\
\text { Estinate }\end{array}$ & 1.0163 & 1.0040 & 1.0018 & 1.0000 & 1.0109 & 1.0392 \\
\hline $\begin{array}{l}\text { Cumulated Search } \\
\text { Parameter }\end{array}$ & -1.53 & -1.37 & -1.46 & -1.45 & -1.492 & -1.617 \\
\hline $\begin{array}{l}\text { Fissile Inventory } \\
\left(\mathrm{Kgm} / \mathrm{Kw}_{\mathrm{e}}\right)\end{array}$ & 2.275 & 2.311 & 2.317 & 2.320 & 2.285 & 2.197 \\
\hline $\begin{array}{l}\text { Conversion Ratio } \\
\text { adjusted }\left(k_{\text {eff }}=1\right) * *\end{array}$ & 1.0060 & 0.9999 & 0.9990 & 0.9986 & 1.0076 & 1.0148 \\
\hline
\end{tabular}


Here the oscillation without weighting is severe. The optimum value of the weighting factor is about 0.2. A larger value decreases the rate of convergence. The worse the osclllation the larger the weighting factor expected to optimize acceleration. Some care was required to identify when incompletely converged results were close to the real solution or not acceptable.

The dependence of the results on the number of meshpolnts was examined by dolng a calculation with the number of meshpoints doubled. Results are compared below:

\begin{tabular}{|c|c|c|c|c|c|c|c|}
\hline \multirow[t]{3}{*}{ Meshpoints } & \multicolumn{2}{|c|}{$\begin{array}{c}\mathrm{U}^{233} \text { Feed } \\
\text { Rates }(\mathrm{Kgm} / \mathrm{Day}) \\
\end{array}$} & \multirow{3}{*}{$\begin{array}{c}\text { In-Reactor } \\
\text { FIssile } \\
\text { Inventory } \\
\text { (Rgm) }\end{array}$} & \multirow{3}{*}{$\begin{array}{c}\text { Peal } \\
\text { Radial } \\
\text { Average } \\
\text { Power } \\
\text { Density } \\
\left(W_{\text {th }} / \mathrm{cc}\right) \\
\end{array}$} & \multirow{2}{*}{\multicolumn{2}{|c|}{$\begin{array}{l}\text { Breeding } \\
\text { Rat10 }\end{array}$}} & \multirow{3}{*}{$\begin{array}{c}\text { In-Reactor } \\
\text { Fissile } \\
\text { Doubling } \\
\text { Time } \\
\text { (yrs at } 0.9 \\
\text { loading factor) }\end{array}$} \\
\hline & \multirow[t]{2}{*}{ Primary } & \multirow[t]{2}{*}{ Tert1le } & & & & & \\
\hline & & & & & $\begin{array}{l}\text { ReactIon } \\
\text { Rates }\end{array}$ & $\begin{array}{l}\text { Mass } \\
\text { Balance }\end{array}$ & \\
\hline 70 & 11.56 & 32.58 & 4,299 & 13.82 & 1.053 & 1.052 & 53.5 \\
\hline 140 & 11.56 & 32.58 & 4,299 & 13.84 & 1.053 & 1.052 & 53.4 \\
\hline Extrapolated & 11.56 & 32.58 & 4,299 & 13.85 & 1.053 & 1.052 & 53.4 \\
\hline
\end{tabular}

Evidently a sufficient number of meshpoints (70) has been used in these calculations to produce quite adequate accuracy. Single Pebble Size Results

Calculations were done to examine the performance with a single pellet size but two feed streams. The primary pebbles containing fuel from an external source were introduced at the entrance to the core. Fertile pebbles were introduced at the top of an axial blanket. Residence time in the core was made the same for the two streams, and the residence time of the fertile pebbles in the blanket was made inversely proportional to the volume fraction occupied. Results of these one-dimensional calculations treating four neutron energy groups are shown in Table 5. By "cycle" is meant the pass 
Table 5. Results from One-Dimensional Treatment of a Single Pellet Size

\begin{tabular}{|c|c|c|c|c|}
\hline $\begin{array}{l}\text { Cycle and } \\
\text { recycle fraction } \\
\text { Primary/ Fertile }\end{array}$ & $\begin{array}{l}\text { Out of } \\
\text { core } \\
\text { molderp } \\
\text { (Days) }\end{array}$ & C/Th & $\begin{array}{l}\text { Pertile } \\
\text { Perllet } \\
\text { strean } \\
\text { Praction }\end{array}$ & $\begin{array}{l}\text { Power } \\
\text { Peensity } \\
\left(W_{\mathrm{th}} / \mathrm{ccc}\right)\end{array}$ \\
\hline $1 / 1$ & - & 20 & .298 & 6.25 \\
\hline $1 / 1$ & - & \& & .298 & 6.25 \\
\hline $1 / 1$ & - & 20 & .298 & 6.25 \\
\hline $1 / 1$ & - & 80 & .298 & 5.0 \\
\hline $1 / 1$ & - & no & .298 & 5.0 \\
\hline 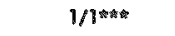 & - & 110 & .298 & 5.0 \\
\hline $1 / 1$ & - & 110 & .298 & 5.0 \\
\hline $1 / n$ & - & 110 & .298 & 5.0 \\
\hline $1 / 1$ & - & 110 & .5 业 & 5.0 \\
\hline $1 / 1$ & - & 110 & .5 & 5.0 \\
\hline $1 / 19$ & - & 110 & .5 & 5.0 \\
\hline $1 / 1$ & - & 110 & .5 & 5.0 \\
\hline $2.7 . / 2,9$. & 30 & 110 & .5 & 5.0 \\
\hline $2,1 . / 2,1$ & 60 & 110 & .5 & 5.0 \\
\hline $2.7 .82,1$ & 120 & 110 & .5 & 5.0 \\
\hline $3,7 . / 3,1$ & 60 & 110 & .5 & 5.0 \\
\hline $4,1 . / 4,1$. & 60 & 110 & .5 & 5.0 \\
\hline $50 / 5.85$ & 60 & 1180 & .5 & 5.0 \\
\hline $6,1 . / 6,85$ & 60 & 110 & .5 & 5.0 \\
\hline $7.1 . / 7 . .85$ & 60 & 1110 & .5 & 5.0 \\
\hline $8.1 . / 8.85$ & 60 & 110 & .5 & 5.0 \\
\hline $9 P / 9.85$ & 60 & 110 & .5 & 5.0 \\
\hline \multicolumn{5}{|c|}{ Inferred Pseudo EquH 1 ubrium with Processed Primary } \\
\hline 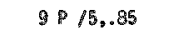 & 60 & 800 & .5 & 5.0 \\
\hline $98 / 1$ & 60 & 100 & .5 & 5.0 \\
\hline $8.1 . / 1$ & 60 & 100 & .5 & 5.0 \\
\hline
\end{tabular}
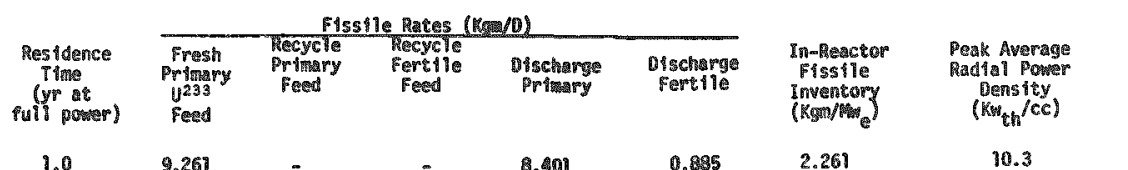

In-Reactor
Breading
Matio
(yissile Doubling Time
(yr at 0.9 load factor)

\begin{tabular}{|c|c|c|c|c|c|c|}
\hline 9.0 & 9.261 & - & - & 8.4017 & 0.285 & 2.261 \\
\hline 0.5 & 17.353 & - & - & 16.4992 & 1.022 & 2.125 \\
\hline 0.25 & 32.898 & - & - & 32.078 & 1.107 & 2.013 \\
\hline 1.0 & 8.896 & $=$ & - & 8.253 & 0.735 & 2.729 \\
\hline 2.0 & 3.820 & - & - & 3.299 & 0.5621 & 2.331 \\
\hline 8.0 & 6.949 & - & . & 6.322 & 0.7194 & 2.148 \\
\hline 0.5 & 13.290 & - & - & 12.705 & 0.8328 & 2.047 \\
\hline 0.25 & 25.602 & $=$ & . & 25.023 & 0.8991 & 1.963 \\
\hline 2.0 & 3.826 & - & - & 2.620 & 1.200 & 2.336 \\
\hline 1.0 & 6.956 & . & - & 5.572 & 1.537 & 2.150 \\
\hline 0.5 & 13.317 & . & - & 11.786 & 1.776 & 2.051 \\
\hline 0.25 & 25.596 & - & - & 24.006 & 1.920 & 1.963 \\
\hline 0.25 & .891 & 24.005 & 1.920 & 23.505 & 3.590 & 2.065 \\
\hline 0.25 & .753 & 24.006 & 1.920 & 23.378 & 3.5938 & 2.055 \\
\hline 0.25 & .650 & 24.006 & 1.920 & 23.283 & 3.537 & 2.048 \\
\hline 0.25 & .696 & 23.378 & 3.538 & 22.258 & 4.915 & 2.135 \\
\hline 0.25 & .786 & 22.858 & 4.915 & 22.514 & 6.096 & 2.211 \\
\hline 0.25 & 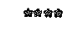 & 21.240 & 5.181 & 20.350 & 6.358 & 2.062 \\
\hline 0.25 & 1.678 & 20.350 & 5.404 & 21.107 & . .538 & 2.137 \\
\hline 0.25 & 1.677 & 21.107 & 5.557 & 21.825 & 6.659 & 2.204 \\
\hline 0.25 & 3.721 & 21.825 & 5.650 & 22.558 & 6.739 & 2.268 \\
\hline 0.25 & mat & 28.611 & 5.728 & 20.778 & 6.820 & 2.135 \\
\hline 0.25 & - & 22.38 & 6.86 & 21.67 & 7.77 & 2.29 \\
\hline 0.25 & - & 21.851 & 5.181 & 20.971 & 6.349 & 2.109 \\
\hline 0.25 & - & 27.039 & . & 25.514 & 1.860 & 2.073 \\
\hline 0.25 & - & 28.803 & - & 27.158 & 1.798 & 2.198 \\
\hline
\end{tabular}

10.3
10.2
10.2
7.98
9.81
8.34
8.36
8.60
9.81
8.35
8.23
8.59
8.19
8.37
8.49
8.32
8.28
8.40
8.28
8.26
8.24
8.34
8.21
8.36
8.46
8.36

1.0059
1.0396
1.0618
1.0284
0.9976
1.0474
1.0673
1.0891
0.998
1.0417
1.0657
1.0503
1.0622
1.0697
1.0566
1.0940
1.0249
1.0786
1.0580
1.0906
1.0247
1.0707
1.0593
1.0795
1.0595
1.0426
419.
61.4
32.0
84.6
53.7
30.6
22.0
51.0
30.6
21.7
33.2
33.2
31.7
30.7
48.6
89.3
26.2
36.2
36.9
92.7

"Akia? Blanket 41.3 en thick for this fraction.

* Axial Blanket $95 . \mathrm{cm}$ thick for this fraction.

"whe This case was also run with the cross sections for a C/Th of 80 giving a breeding ratio of 1.0347 .

Reprocessed prtanary pebble uranium mixture from cycle 4 eycles 5-8 as foed anterfal 8.943 fraction neaded cycle 5). 
through the reactor of the pebbles. If the feed for the primary pebbles was processed to remove non-uranium nuclides, a $\mathbb{P}$ is shown. The recycle fraction of the discharge from the prevlous cycle used as feed is also shown. Considerable uncertainty is admitted in the resonance shielding calculation, so the dependence shown on $\mathrm{C} / \mathrm{Th}$ is at best only approximate. Reduction in the power density from 6.25 to $5 \mathrm{~W}_{\mathrm{th}} / \mathrm{cc}$ reduces the design capacity from 1,500 to $1,200 \mathrm{Mw}_{\mathrm{e}}$

The recycle calculations were done by simply recycling a fraction of the fertile pebbles. With discrete steps of fueling and fractional recycle, the effective average residence time is given by

$$
\theta=T(1-f) \sum_{n=1}^{\infty} n(f)^{n-1} \text {, or }
$$

approximately $\theta \simeq \frac{T}{(1-f)}$ for continuous feed, where $f$ is the fraction recycle and $T$ the residence time. For $T=90$ days and $E=0.85, \theta$ is about 660 days. For a blanket residence time of 90 days and a holdup time out of core of 60 days, the residence time in the system averages about 1173 days, 73 days in the blanket, 660 days in the core and 440 days out of the reactor.

It appears essential to selectively remove highly exposed pebbles. Perfect selectivity reduces the average exposure time to

$$
\theta=\frac{T}{(\mathbb{N}+1)\left(1-\frac{N f}{2}\right)}
$$

where $\mathbb{N}=\frac{1}{(1-f)}$ truncated to an integer. For this model the above data yields a residence time of 364 days in the core.

If detalled calculations were made for selective discharge of mater1als, $N+1$ pebble streams would have to be followed and exposure treated 
independently. A linear approximation may be made to estimate the equivalent recycle fraction with selection, for the value of the continuous recycle fraction used, but mass balances must be preserved.

The early history was followed in Table 5 of a plant operated with a 0.25 year core residence time, 60 day hold up, and then recycle of pebbles. This information is used to construct a mass balance history for a 1,200 Mw plant which allows for the out of core inventory in the loops and feed material on hand. A ten year history (11.1 years at 0.9 load factor) is estimated as follows:

\begin{tabular}{cc|c|c|c|cc}
\hline $\begin{array}{c}\text { Year at } \\
\text { Fu11 Power }\end{array}$ & $\begin{array}{c}\text { Breeding } \\
\text { Ratio }\end{array}$ & Reactor & $\begin{array}{c}\text { Primary } \\
\text { Loops }\end{array}$ & System & $\begin{array}{c}\text { Fissile } \\
\text { Feed } \\
\text { (Kgm) }\end{array}$ & $\begin{array}{c}\text { Fissile } \\
\text { Discharge } \\
\text { (Kgm) }\end{array}$ \\
\hline 0 & & 2,107 & 2,107 & 3,407 & 3,407 & \\
1 & 1.061 & 2,600 & 4,279 & 5,580 & 2,091 & \\
2 & 1.054 & 2,650 & 4,362 & 6,740 & 3,249 & 2,161 \\
3 & 1.051 & 2,700 & 4,444 & 7,644 & 3,010 & 2,174 \\
4 & 1.049 & 2,740 & 4,510 & 7,710 & 2,186 & 2,186 \\
5 & 1.048 & 2,770 & 4,559 & 7,759 & 2,181 & 2,196 \\
6 & 1.047 & 2,790 & 4,592 & 7,792 & 2,175 & 2,205 \\
7 & 1.046 & 2,810 & 4,625 & 7,825 & 2,182 & 2,211 \\
8 & 1.045 & 2,830 & 4,658 & 7,858 & 2,188 & 2,215 \\
9 & 1.045 & 2,850 & 4,691 & 7,891 & 2,191 & 2,218 \\
10 & 1.044 & 2,870 & 4,724 & 7,924 & 2,195 & 2,221 \\
\hline
\end{tabular}

If one considers a one year residence time ( 1.11 year at .9 load factor), a lead time of 0.5 and 1 g time of 1.0 real years, the ratio of the associated total fissile inventory to that in the reactor is 2.35 . The ratio in the above estimate of mass balances is 2.76 .

Using a fissile consumption rate of $1.112 \mathrm{Kgm} / \mathrm{MW}$ e $\mathrm{yr}$, the plant consumption is $1334 \mathrm{Kgm} / \mathrm{yr}$. For a breeding ratio of 1.049 , the annual 
production is $65.4 \mathrm{Kgm}$ fissile. The time required to produce enough fuel to Inventory a second plant and associated system with an inventory of $7,924 \mathrm{kgm}$ Is 135 years, at a load factor of 0.9 . Note that the annual fuel production is less than one percent of the system inventory. Note also that of the required inventory of $7.924 \mathrm{Kgm}$ after 11 years, only $654 \mathrm{Kgm}$ were produced, requiring an external feed of $\mathrm{U}^{23}$ of $7,274 \mathrm{Kgm}$. There is breedIng potent1al, but $0^{235}$ fuel will have to be used for a long time.

Processing losses were Ignored in the analysis above. The effect of fraction processing loss for the ten year history is shown below considerIng that all discharged fuel and the final on hand inventory would be processed:

\begin{tabular}{cccc}
\hline $\begin{array}{c}\text { Processing } \\
\text { Loss } \\
\text { (Percent) }\end{array}$ & $\begin{array}{c}\text { Net Year } \\
\text { Production } \\
\text { (Kgm) }\end{array}$ & $\begin{array}{c}\text { Fraction } \\
\text { of System } \\
\text { Inventory }\end{array}$ & $\begin{array}{c}\text { Effective } \\
\text { Breeding } \\
\text { Ratio }\end{array}$ \\
\hline & & & \\
0 & 654 & .082 & 1.049 \\
0.5 & 541 & .068 & 1.041 \\
1.0 & 429 & .054 & 1.032 \\
1.5 & 316 & .040 & 1.024 \\
2.0 & 203 & .025 & 1.015 \\
2.5 & 90 & .011 & 1.007 \\
\hline
\end{tabular}

The data presented allows an estimate to be made of the fuel cost. Considering a thirty year operation at 0.9 load factor, fissile value of $\$ 35 / \mathrm{gm}, 0.07 \mathrm{discount}$ factor, and other parameters used earlier in this study, the following results are obtalned in mils/Kwe $\mathrm{hr}$ using $0.07 \mathrm{dis}-$ count factor compounded quarterly:

\begin{tabular}{lccc}
\multicolumn{1}{c}{ Cost } & Direct & Indirect & Tota1 \\
Fabrication & 2.43 & .29 & 2.72 \\
Processing & 1.82 & -.34 & 1.48 \\
Fuel & $\underline{-.07}$ & $\underline{3.21}$ & $\frac{3.14}{3.16}$ \\
Total & 4.18 & 7.34
\end{tabular}


Data were presented in Table 5 for a second cycle considering out of reactor hold up periods of 30,60 and 120 days. Coarse economic analysis was done for the mass balances. Although the breeding ratio can indeed be increased by such holdup, the fuel cost was significantly increased due to the increase in pebble and fissile inventorles. No economic incentive was found to justify such holdup.

The dependence of fuel cost on residence time is estimated for a first cycle as follows (mils/Kw $\mathrm{hr}$ ):

\begin{tabular}{|c|c|c|c|c|}
\hline Residence Time (Yr) & 0.25 & 0.5 & 1.0 & 2.0 \\
\hline Tabrication & 8.81 & 4.41 & 2.20 & 1.10 \\
\hline Processing & 6.55 & 3.27 & 1.63 & .80 \\
\hline Fue1 & .17 & .05 & .02 & .12 \\
\hline Indirect & 5.55 & 3.38 & 2.27 & 1.75 \\
\hline Total & 21.08 & 11.11 & 6.12 & 3.77 \\
\hline
\end{tabular}

Note that the mode of operation is forced to a long residence time to achieve reasonably low cost of electrical energy.

\section{Early Operation}

One-dimensional problems were solved to examine the behavior of the single pebble concept with two pebble streams using $U^{235}$ fuel. The primary pebbles containing fuel were introduced at the top of the core while fertile pebbles were introduced at the top of an inlet axial blanket $45 \mathrm{~cm}$. thick. Both fully enriched $\mathrm{U}^{235}$ and low enriched (high security quality) $U^{235}$ feed were considered. The results are summarized in Table 6 for a power density of $5 \mathrm{w}_{\mathrm{th}} / \mathrm{cc}$ in a $1,200 \mathrm{Mw}_{\mathrm{e}}$ plant. A special qualification is placed on these calculations because additional effort should be invested in improving the accuracy of the resonance shielding and its dependence on the nuclide concentrations and carbon to heavy metal ratio. The reference C/HM was 160 . 
Table 6. Reoults for One Febble 59 ate and $\mathrm{U}^{295}$ Fuel

(Cne Dimenstona1, Four Group Calculations)

\begin{tabular}{|c|c|c|c|c|c|c|}
\hline Case & $\mathrm{Cl}$ & C2 & $\mathrm{c3}$ & 64 & $\mathrm{cs}$ & C6 \\
\hline Feed V Enrlehwent & 0.18 & 0.17 & 0.20 & 0.95 & 0.95 & 0.95 \\
\hline Core Residence Time (YY) & 2. & 2. & 3. & 2. & 3. & 3. \\
\hline cycle & 1 & 2 & 1 & 1 & 1 & $2 *$ \\
\hline $\begin{array}{l}\text { Peak Radial Average } \\
\text { Power Density }\left(W_{\mathrm{th}} / \mathrm{cc}\right)\end{array}$ & 10.9 & 12.5 & 13.9 & 10.0 & 13.3 & 14.9 \\
\hline Conversion Ratio & 0.767 & 0.800 & 0.735 & 0.774 & 0.755 & 0.714 \\
\hline $\begin{array}{l}\text { Fissile Inventory } \\
(\mathrm{kgm} / \mathrm{Mm}) \\
\text { Actinlde Mass Balance }\end{array}$ & $\begin{array}{c}2.258 \\
\left(\mathrm{~N}_{\mathrm{w}} \mathrm{e}^{\left.-\mathrm{Yr}_{\mathrm{T}}\right)}\right.\end{array}$ & 2.043 & 2.398 & 1.813 & 1.867 & 1.986 \\
\hline Feed Th 232 & 28.521 & 28.521 & 19.014 & 32.721 & 21.814 & 21.373 \\
\hline$y^{233}$ & - & 0.43386 & - & - & - & 0.19173 \\
\hline $\mathrm{U}^{234}$ & - & 0.03993 & - & - & - & 0.03346 \\
\hline $0^{235}$ & 1.3273 & 0.76279 & 1.0447 & 1.0890 & 0.85151 & 0.71729 \\
\hline $0^{286}$ & - & 0.14512 & - & - & - & 0.00066 \\
\hline$v^{238}$ & 6.0867 & 5.7251 & 4.0578 & 0.05316 & 0.04211 & 0.03792 \\
\hline DLscharge $\operatorname{th}^{232}$ & 27.837 & 27.810 & 18.370 & 31.816 & 20.960 & 20.584 \\
\hline $\mathrm{ga}^{233}$ & 0.00337 & 0.00260 & 0.00078 & 0.00607 & 0.00129 & 0.00077 \\
\hline $8^{233}$ & 0.43049 & 0.57718 & 0.34784 & 0.49104 & 0.37977 & 0.39883 \\
\hline$u^{234}$ & 0.03993 & 0.09818 & 0.04269 & 0.06149 & 0.06472 & 0.09065 \\
\hline$v^{235}$ & 0.53703 & 0.31112 & 0.31811 & 0.32000 & 0.16796 & 0.17379 \\
\hline$v^{236}$ & 0.14512 & 0.21397 & 0.13194 & 0.13548 & 0.11837 & 0.10021 \\
\hline$u^{238}$ & 5.8723 & 5.5228 & 3.8536 & 0.04684 & 0.03505 & 0.03185 \\
\hline No 239 & 0.00004 & 0.00003 & 0.00001 & - & - & - \\
\hline $\mathrm{Pu}^{239}$ & 0.05100 & 0.04578 & 0.03662 & 0.00100 & 0.00079 & 0.00075 \\
\hline$P u^{240}$ & 0.01889 & 0.01718 & 0.01454 & 0.00040 & 0.00033 & 0.00031 \\
\hline $\mathrm{Pu}^{241}$ & 0.01786 & 0.01672 & 0.01521 & 0.00047 & 0.00040 & 0.00038 \\
\hline $\mathrm{Pu}^{242}$ & 0.00561 & 0.00566 & 0.00697 & 0.00026 & 0.00034 & 0.00028 \\
\hline $\operatorname{Am} 243$ & 0.00065 & 0.00066 & 0.00119 & 0.00003 & 0.00007 & 0.00005 \\
\hline \multicolumn{7}{|c|}{ Meutron Accounting (Fraction Aboorpthons) } \\
\hline Fissile & 0.50936 & 0.49631 & 0.50706 & 0.49811 & 0.49331 & 0.49080 \\
\hline Tertile & 0.39408 & 0.39946 & 0.37654 & 0.38878 & 0.37048 & 0.35255 \\
\hline other Actinides & 0.00485 & 0.01002 & 0.00688 & 0.00484 & 0.00652 & 0.00513 \\
\hline $\mathrm{C}$ & 0.01341 & 0.01399 & 0.01202 & 0.01838 & 0.01685 & 0.01545 \\
\hline Fission Product: & 0.06714 & 0.06660 & 0.08288 & 0.07834 & 0.09734 & 0.12006 \\
\hline Other & 0.01116 & 0.01362 & 0.01462 & 0.01155 & 0.01530 & 0.01601 \\
\hline Total & 1.0 & 1.0 & 1.0 & 1.0 & 1.0 & 1.0 \\
\hline
\end{tabular}

*only Eertlle pebble recycled whout reprocessing. 
With recycle of high $\mathrm{U}^{23}$ content material, the amount of fissile material in the total reprocessed stream decreases with a conversion ratio well below unity. If makeup material is added which also has a high $\mathrm{U}^{23}$ content, the feed uranium entichment decreases with time. Elther this decreased enrichment must be used and the thorium feed reduced, or highly enriched $U^{235}$ feed be added as makeup. The former would reduce the $U^{23}$ production and increase plutonium generation, reducing the conversion ratio.

Continuing recycle calculations were done with fixed $\mathrm{U}^{238}$ feed (two cycles shown in Table 5), and the calculated conversion ratio increases with increase in $U^{23}$ feed for the cycles starting with the first cycle as follows: $.767, .800, .829, .834, .837$.

Fuel costs determined for the case of the early history with $U^{23}$ feed with $\mathrm{Pu}$ throwaway are as follows (mils/Kw $\mathrm{hr}$ ):

\begin{tabular}{lcccccc}
\multicolumn{1}{c}{ Case } & C1 & C2 & C3 & C4 & C5 & C6 \\
$\begin{array}{l}\text { Cycle } \\
\text { Residence time (yr) }\end{array}$ & 2 & 2 & 1 & 1 & 1 & 2 \\
$\quad \begin{array}{l}\text { - Basis - } \\
\text { Reference }\end{array}$ & 3.22 & 3.44 & 2.93 & 2.84 & 2.50 & 2.78 \\
Devalued fue1 & 3.33 & 3.66 & 3.05 & 2.99 & 2.63 & 2.89 \\
Throwaway fue1* & 5.65 & 5.77 & 4.48 & 4.56 & 3.57 & 3.81 \\
Credit only fertile & 4.86 & 5.00 & 3.92 & 3.78 & 3.00 & -
\end{tabular}
pebble fuel

Ore requirements are estimated from first cycle in $\mathrm{Mgm} \mathrm{U}_{3} \mathrm{O}_{8} / \mathrm{MW}_{\mathrm{e}}$ capacity at 0.9 load factor, and approximated for recycle as followe:

Case

\section{Reactor inventory}

System inventory

Full fisslle credit

30 year use

30 year total

No fissile credit

30 year use

30 year total

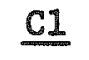

.476

.832

2.120

2.952

7.550

8.382

Fertile pebble fuel credit on $1 y$

30 year total 7.197

Approximated for delayed recycle, full

30 year use

30 year total

1.456

2.288
C3

.506

.758

2.217

2.975

5.943

6.701

4.983

5.741

2.077

2.835

* No charge for shipping and long-term storage. 
Using the data on page 48 for once-recycle of unprocessed fertile pebbles with fully enriched $U^{235}$ feed, and fissile throwaway, the fuel cost is estimated at $3.25 \mathrm{mils} / \mathrm{kw} \mathrm{e}$. The 30 -year ore requirement at a plant factor of 0.9 is estimated at $5.0 \mathrm{Mgm} \mathrm{U}_{3} \mathrm{O}_{8} / \mathrm{Mr}$ capacity for inventory and make up, a 10 percent reduction over full throwaway. This could evidently be Improved by loading the fertile pebbles with more than half of the thorium, and further assessment is needed considering the decrease in conversion ratio and the possible gain by increasing the $\mathrm{C} / \mathrm{Th}$ ratio.

The dependence of the fuel cost of produced electricity on the unit charges and indirect cost rate is shown below for case $C 4$; note that the handiing cost should include fabrication, processing, shipping, disposal, etc., and a total reference cost of $350 \$ / \mathrm{kgm}$ has been used in this study:

$\begin{array}{lllll}\text { Indirect Charge Rate } & 0.07 & 0.10 & 0.13 & 0.16\end{array}$ Unit Handling Charge (\$/kgm)

$\begin{array}{rrrrr}150 & 1.67 & 2.02 & 2.37 & 2.71 \\ 300 & 2.30 & 2.64 & 2.99 & 3.33 \\ 450 & 2.92 & 3.26 & 3.61 & 3.95 \\ 600 & 3.53 & 3.88 & 4.23 & 4.57 \\ 750 & 4.15 & 4.50 & 4.85 & 5.19 \\ 1000 & 5.19 & 5.54 & 5.89 & 6.23 \\ 1250 & 6.23 & 6.58 & 6.93 & 7.27\end{array}$

Our economic assessment indicates that the fissile and fertile loading should be reduced to minimize the fuel cost. Likely, the optimum C/Th is we11 above 110 for $U^{233}$ feed is needed and above 160 for $U^{235}$ feed.

Further, to minimize ore consumption, a very long residence time of $U^{235}$ feed is needed and a high $\mathrm{C} / \mathrm{Th}$. It appears that the calculations done toward the end of this study may overestimate the thorium resonance shieldIng for relatively small pebbles causing the fissile inventory to be underestimated.

The one-dimenslonal results reported above assume effective reflection of neutrons at the edge of the core. To achieve the low radial leakage which was assumed, a radial blanket of thorium pellets of some form would be required. 


\section{Two-Dimensional Results}

The whole reactor was described with a two-dimensional $(R-Z)$ model. Calculations were done treating 2,4 and 8 energy groups with the oncethrough fuel movement followed in five regions of equal volume (axial flow in radial annuli). Results are shown in Table 7 , which were obtained early in the effort treating 8 energy groups with a C to Th ratio of 88. A discrepancy in the assigned $C$ density to the reflector caused the effective radial blanket thickness to be less than intended in the cases run initially.

Two-dimensional survey calculations were done treating four neutron energy groups. The residence time was varied over five flow paths (as above), the axial blanket was $51.6 \mathrm{~cm}$ thick at the entrance, and a fixed $36 \mathrm{~cm}$ radial blanket was included. The thorium loading was fixed and the carbon varied, and somewhat different resonance shielding parameters were used in this assessment. Uncertainty in the resonance shielding treatment causes inaccuracy in the intended parameter changes. Results are shown in Tables 8 and 9.

The fuel cost dependence on residence time is estimated as follows assuming an average residence time of 5 full power years for the fertile pellets and blanket for a power density of $5 \mathrm{w}_{\text {th }} / \mathrm{cc}$ :

$\begin{array}{lcrr}\text { Residence Time (yr) } & .5 & 1 . & 2 . \\ \text { Cost Component } & & & .92 \\ \text { Fabrication } & 1.93 & 1.24 & .71 \\ \text { Processing } & 1.47 & .95 & \underline{3.75} \\ \text { Indirect } & \underline{5.42} & \underline{4.14} & 5.38 \\ \text { Total } & 8.82 & 6.33 & \end{array}$


Table 7. Results for the Two-Ball Pebble Bed Reactor

(Two-Dimensional, Elght Group, Fresh $\mathrm{U}^{233}$ Feed, Axlal Blanket)

\begin{tabular}{|c|c|c|c|c|c|c|c|c|c|c|c|}
\hline \multirow{2}{*}{$\begin{array}{c}\text { Power } \\
\text { Leve1 } \\
\left(w_{\mathrm{th}} / \mathrm{cc}\right)\end{array}$} & \multirow{2}{*}{$\begin{array}{l}\text { Radial } \\
\text { Reflector } \\
\text { (cm) }\end{array}$} & \multicolumn{2}{|c|}{ Blankets (cm) } & \multicolumn{2}{|c|}{$\begin{array}{l}\text { Residence } \\
\text { Time (yr) } \\
\end{array}$} & \multicolumn{2}{|c|}{$\begin{array}{c}\text { F1ssile Feed } \\
\text { Rates (Fga/day) } \\
\end{array}$} & \multirow{2}{*}{$\begin{array}{l}\text { In-Reactor } \\
\text { Iissile } \\
\text { Inventory } \\
\text { (Rgi) }\end{array}$} & \multirow{2}{*}{$\begin{array}{c}\text { Peak } \\
\text { Power } \\
\text { Density } \\
\left(w_{\text {th }} / \mathrm{cc}\right)\end{array}$} & \multirow[t]{2}{*}{$\begin{array}{l}\text { Breeding } \\
\text { Ratio }\end{array}$} & \multirow{2}{*}{$\begin{array}{c}\text { In-Reactor } \\
\text { Fissile } \\
\text { Doubling TIme } \\
\text { (yr at } 0.9 \\
\text { load factor) }\end{array}$} \\
\hline & & Axtal & RadLa1 & Primary & Fertle & Prgำary & Fertile & & & & \\
\hline 6.25 & 4.2 & 31 & 0 & 1 & .1 & 12.29 & 31.71 & 5,325 & 23.85 & 0.974 & - \\
\hline 6.25 & 4.2 & 31 & 0 & 1 & $.1 * \%$ & 12.34 & 34.66 & 5,346 & 23.63 & 0.972 & - \\
\hline 6.25 & 8.4 & 31 & 0 & $1 *$ & $.1 *$ & 12.11 & 31.71 & 5,263 & 23.06 & 0.978 & - \\
\hline 6.25 & 8.4 & 31 & 0 & $1 *$ & $.1 *$ & 12.11 & 34.66 & 5,475 & 25.42 & 0.995 & - \\
\hline 6.25 & 16.8 & 31 & 0 & 1 & .1 & 11.84 & 31.71 & 5,176 & 22.22 & 0.981 & - \\
\hline 6.25 & 16.8 & 31 & 0 & 1 & $.1 *$ & 11.78 & 34.66 & 5,147 & 22.33 & 0.983 & - \\
\hline 6.25 & 16.8 & 31 & 0 & $1 *$ & $.1 *$ & 11.91 & 34.66 & 4,919 & 24.27 & 0.997 & - \\
\hline 6.25 & 90 & 31 & 0 & $I$ & $.1 *$ & 10.33 & 34.66 & 4,378 & 16.16 & 1.007 & 360 \\
\hline 5.0 & 90 & 31 & 0 & $1 *$ & $.1 *$ & 9.471 & 34.66 & 4,198 & 12.13 & 1.025 & 136 \\
\hline 6.25 & 12.6 & 31 & $24 \%$ & 1 & .1 & 11.73 & 31.71 & 5,701 & 21.54 & 1,0086 & 435 \\
\hline 6.25 & 12.6 & 31 & $24 \% * *$ & $1 *$ & $.1 *$ & 11.80 & 34.66 & 5,576 & 23.65 & 1.0201 & 182 \\
\hline 6.25 & 12.6 & 31 & $36 * * *$ & 1* & $.1 *$ & 11.80 & 34.66 & 5,415 & 23.62 & 1.0333 & 107 \\
\hline 6.25 & 12.6 & 31 & 36 & $1^{\text {* }}$ & $.1 *$ & 11.91 & 34.66 & 4,950 & 24.27 & 1.0380 & 85 \\
\hline 6.25 & 12.6 & 52 & 36 & $1 *$ & $.1 *$ & 11.89 & 34.66 & 5,061 & 24.18 & 1.0471 & 66 \\
\hline 6.25 하의 & 90 & 52 & 36 & $1^{*}$ & $.1 \%$ & 14.32 & 34.66 & 5,862 & 22.44 & 1.0575 & 60 \\
\hline
\end{tabular}

*Residence time varied in proportions $0.6,0.8,1,1.2,1.4$ in the five paths of equal volumes radially outward

**Residence time inverted from *.

*ththese cases have a few years exposure products in the radial blanket.

*mo $/ \mathrm{Th} 80$ in core instead of 88 
Table 8. Two-Dimensional Results for the Two Pebble Reactor

\begin{tabular}{|c|c|c|c|c|c|c|c|c|c|c|c|}
\hline \multirow{3}{*}{$\mathrm{C} / \mathrm{Th}$} & \multirow{2}{*}{\multicolumn{2}{|c|}{$\begin{array}{c}\text { Residence Times* } \\
\text { (yrs) }\end{array}$}} & \multirow{3}{*}{$\begin{array}{l}\text { Power } \\
\text { Density } \\
\left(W_{t h} / c c\right)\end{array}$} & \multicolumn{4}{|c|}{$\frac{\text { Fissile Mass Balance }}{\text { (Races, Rgm/Day) }}$} & \multirow{3}{*}{$\begin{array}{l}\text { In-Reactor } \\
\text { Fissile } \\
\text { Inventory } \\
\text { (Kgm/Mw })\end{array}$} & \multirow{3}{*}{$\begin{array}{l}\text { Peak } \\
\text { Average } \\
\text { Power } \\
\text { Density } \\
\text { (Kith } / \text { cc) }\end{array}$} & \multirow{3}{*}{$\begin{array}{l}\text { Breeding } \\
\text { Ratio }\end{array}$} & \multirow{3}{*}{$\begin{array}{c}\text { In-Reactor } \\
\text { Fisslie } \\
\text { Doubling TIme } \\
\text { (yr. at } 0.9 \\
\text { load factor) }\end{array}$} \\
\hline & & & & \multicolumn{2}{|c|}{ Feed } & \multicolumn{2}{|c|}{ Discharge } & & & & \\
\hline & Primary & Fertile & & Primary & Fertile & Primary & Fertile & & & & \\
\hline 80 & 1. & .1 & 6.25 & 12.991 & 34.66 & 10.868 & 36.79 & 3.618 & 23.13 & 1.0565 & 62.4 \\
\hline 110 & 1. & .1 & 6.25 & 7.961 & 34.66 & 6.336 & 36.38 & 2.517 & 28.75 & 1.0600 & 41.3 \\
\hline 110 & 1. & .1 & $5.0 \%$ & 12.020 & 0 & 9.495 & 2.624 & 2.926 & 26.37 & 1.0670 & 43.0 \\
\hline 110 & 1. & .1 & $5.0 \%$ & 7.292 & 34.66 & 6.064 & 36.03 & 3.037 & 20.68 & 1.0783 & 38.4 \\
\hline 110 & 2. & .1 & $5.0 \% \%$ & 4.565 & 34.66 & 3.201 & 36.05 & 3.239 & 26.52 & 1.0470 & 68.2 \\
\hline
\end{tabular}

Residence time distribution: $0.6,0.8,1,1.2,1.4$ in five flow paths.

** Reduced power density means lower plant design capacity, a reduction from $1,500 \mathrm{Mw}_{\mathrm{e}}$ to $1,200 \mathrm{Mw} \mathrm{e}^{\circ}$ 
Table 9. Results for the Two Pebble Concept

(Two-Dimensione1, Four-Group Calculations)

\begin{tabular}{|c|c|c|c|c|c|c|}
\hline Case & LI & L2 & L3 & 24 & L5 & L6 \\
\hline C/Th & 80 & 110 & 140 & 110 & 110 & 110 \\
\hline $\begin{array}{l}\text { Power Density } \\
\left(w_{t h} / \mathrm{cc}\right)\end{array}$ & 6.25 & 6.25 & 6.25 & 5.0 & 5.0 & 5.0 \\
\hline $\begin{array}{l}\text { Core Residence } \\
\text { Time (yr) } \\
\text { Primary/Fertile }\end{array}$ & $1 . / .1$ & $1 . / .1$ & 1.1 .1 & $.5 / .1$ & $1 . / .1$ & $2 . / .1$ \\
\hline Breeding Ratio & 1.0565 & 1.0600 & 1.0630 & 1.1020 & 1.0783 & 1.0470 \\
\hline Doubling Time (yr) & 62.4 & 41.3 & 32.9 & 28.1 & 38.4 & 68.2 \\
\hline \multicolumn{7}{|c|}{ Actinide Mass Balance ( $\mathrm{Kgm} / \mathrm{Mw}_{\mathrm{w}} \mathrm{e}^{-\mathrm{yr}}$, including radial blanket) } \\
\hline \multirow{2}{*}{$\begin{array}{l}\text { Feed } \operatorname{Th}^{232} \\
U^{233}\end{array}$} & 694.0 & 694.0 & 694.0 & 893.7 & 867.5 & 854.4 \\
\hline & 11.595 & 10.371 & 9.828 & 14.332 & 12.760 & 11.931 \\
\hline \multirow{2}{*}{$\begin{array}{r}\text { Discharge } \mathrm{Th}^{232} \\
\mathrm{~Pa}^{233}\end{array}$} & 692.7 & 692.7 & 692.7 & 892.3 & 866.1 & 853.1 \\
\hline & .490 & .447 & .466 & .560 & .495 & .444 \\
\hline $\mathrm{U}^{233}$ & 11.16 & 9.954 & 9.425 & 13.883 & 12.347 & 11.529 \\
\hline$U^{234}$ & .151 & .140 & .164 & .136 & .138 & .135 \\
\hline $\mathrm{U}^{235}$ & .008 & .007 & .006 & .003 & .006 & .010 \\
\hline $\begin{array}{l}\text { Fissile Inventory } \\
\left(\mathrm{kgm} / \mathrm{MW}_{\mathrm{e}}\right)\end{array}$ & 3.618 & 2.517 & 2.077 & 2.889 & 3.037 & 3.239 \\
\hline \multicolumn{7}{|c|}{ Neutron Loss Accounting (Fraction Absorptions by Nuc11de) } \\
\hline $\mathrm{Th}^{232}$ & .48833 & .48563 & .48298 & .50195 & .49279 & .47694 \\
\hline $\mathrm{Pa}^{233}$ & .00588 & .00739 & .00823 & .00505 & .00607 & .00658 \\
\hline$U^{23}$ & .45648 & .45109 & .44660 & .44913 & .45058 & .45028 \\
\hline$u^{234}$ & .00368 & .00333 & .00298 & .00137 & .00263 & .00502 \\
\hline$U^{235}$ & .00028 & .00038 & .00043 & .00007 & .00025 & .00087 \\
\hline$X e^{135}$ & .01247 & .01641 & .01809 & .01604 & .01548 & .01569 \\
\hline $\mathrm{Nd}^{243}$ & .00089 & .00135 & .00162 & .00065 & .00112 & .00198 \\
\hline $\mathrm{Pm}^{147}$ & .00133 & .00126 & .00114 & .00060 & .00103 & .00171 \\
\hline $\mathrm{Pm}^{348 \mathrm{~m}}$ & .00043 & .00044 & .00041 & .00019 & .00034 & .00060 \\
\hline $\operatorname{Pm}^{146}$ & .00022 & .00020 & .00018 & .00008 & .00014 & .00027 \\
\hline $\mathrm{Sm}^{149}$ & .00312 & .00321 & .00318 & .00272 & $: 00299$ & .00339 \\
\hline \multirow[t]{2}{*}{ Other } & .01138 & .01085 & .01005 & .00463 & .00871 & .01666 \\
\hline & .00462 & .00910 & .01482 & .01041 & .00946 & .00865 \\
\hline $\begin{array}{l}\text { Other losses } \\
\text { Total }\end{array}$ & $\frac{.01089}{1.0}$ & $\frac{.00936}{1.0}$ & $\frac{.00929}{1.0}$ & $\frac{.00542}{1.0}$ & $\frac{.00841}{1.0}$ & $\frac{.01136}{1.0}$ \\
\hline
\end{tabular}


The requirement to inventory the volume associated with hold up of the fertlle streams places a high demand on fuel feed in the early history. For a 120 day hold up of a feed rate of $.03 \mathrm{kgm} / \mathrm{D} / \mathrm{MW}_{\mathrm{e}}$, the amount would

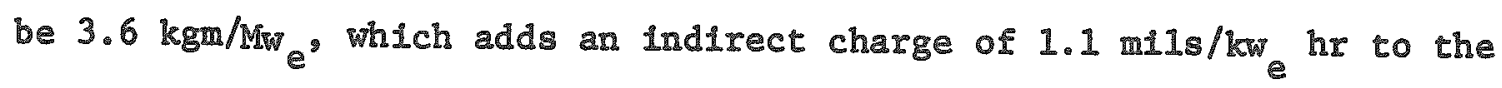
thirty year fuel cost.

\section{Further Discussion}

It appears possible to provide for trim and safety shutdown with control rods, although not simply. Rod tubes may be required with associated structure. Trim control is likely necessary to compensate for the tendency of the flux to roll around the core, and perhaps for load following. Also trim can be expected to be necessary to compensate for fuel addition and removal which could be increased with small pebbles flowing between large ones. Control rod absorptions have not been included in the calculations: performance would be degraded.

It may not be practical to achieve the fertile loadings considered, especially that in the small fert1le pellets. Further assessment is needed of the inner structure and outer coating required on the pebbles. At the low rate of fissile production achievable with this reactor concept with $U^{233}$ fuel without serious economic penalty by high fuel cost, the availability of $\mathrm{U}^{23}$ to inventory plants would lie far in the future. Thus it appears desirable to place primary emphasis on the performance with $U^{235}$ feed and uranium recycle in continuing analysis. More attention is needed in the areas of resonance shielding, fission product treatment, axial leakage, economic optimum configuration and modeling of the reactor with selective recycle. There is special need to calculate a quasi-equilibrium condition involving a snapshot of the reactor under some defined state of 
partiel recycle after hold up of discharged materlal with reprocessing and make up feed. There is some difficulty fabricating an accurate reactor history from snapshots of continuous fueling conditions, which is not simply resolved; only an approximation can be made of the reactor history which becomes less accurate as impacted by hold up and more than one residence condition.

Possible alternatives should be considered which will reduce the cost of the electricity product. This implies reducing the associated system fissile inventory. While it is true that fertile pebbles can be used as blanket material prior to insertion in the core, the economic optimum configuration and mode of optimum has not been identified for a practical design. Increases in system inventory for blankets and out-of-core hold up add significant indirect costs. The cost of the reactor should be considered (capital charges) and acceptable rates used for all indirect costs, costs for fabrication and processing, and fuel worth. More attention should be paid to establishing the maximum allowable local power density, limiting exposure, and minimizing the power peaking to minimize the core size and cost.

Realistic economic projection requires better estimates of unit costs for fabrication, reprocessing and disposal. The data used herein are undoubtedly low estimates, possibly applicable to a very large industry. Complications which should be taken into account are the projected throughput requirements, dependence on pebble design and loading, and higher fabrication load than processing load in an expanding industry.

There are also technical questions to be addressed which involve practical considerations. It is not clear that feed pebbles can easily 
be distributed and then discharged adequately as well as selectively removed for reprocessing.

\section{Acknowledgements}

B. A. Worley did support calculations in this effort, G. W. Cunningham programming for the VENTURE-BURNER model and A. Houston for the typing. A major contribution to this effort was the information provided by C. Lee (LASI) about the calculations made with the FRG methods and considerations about the analysis of the reactor concept. 


\section{REFERENCES}

1. E. Teuchert, H. J. Rutten, K. A. Hass, "Pebble Bed HTR with Once Through Fuel Cycle," KFA Julich Report 25.4., Germany (1977).

2. "Pebble Bed Thermal Breeder Fuel Cycle Considerations," GE Keport CO0-4057-1, ESTD 76-08 (1977).

3. ORNL point model reactor computer code PREMOR (to be documented).

4. D. R. Vondy, T. B. Fowler, G. W. Cunningham, "VENTURE: A Code Block for Solving Multigroup Neutronics Problems Applying the Finite-Difference Diffusion-Theory Approximation to Neutron Transport, Version II," Oak Ridge National Laboratory report ORNL-5062 (1977).

5. D. R. Vondy and G. W. Cunniggham, "Exposure Calculation Code Module BURNER, "Oak Ridge National Laboratory report ORNL-5180 (to be published).

6. N. M. Green, et. a1. "AMPX - A Modular Code System to Generate Coupled Multigroup Neutron-Gamma Cross Sections from ENDF/B," Oak Ridge National Laboratory report ORNL-TM-3706 (1976).

7. J. M. Bel1, "ORIGEN - The ORNL Isotope Generation and Depletion Code, ${ }^{\text {" }}$ USAEC Report ORNL-4628 (1973). 
ORNL/TM-6142

Distribution

Category UC -77

INTERNAL DISTRIBUTION

1. L. S. Abbott

2-21. D. E. Bartine

22. J. T. Bradbury

23. T. J. Burns

24. W. L. Carter

25. J. C. Cleveland

26. D. E. Ferguson

27. G. F. Flanagan

28. A. J. Frankle

29. E. H. Gift

30. H. Goldstein (Consultant)

31. F. J. Homan

32. D. Ingersoll

33. J. D. Jenkins

34-35. P. R. Kasten

36. A. L. Lotts

37. F. C. Maienschein

38. A. R. Olsen

39. H. Postma
40. J. P. Renier

41. C. O. Slater

42. I. Spiewak

43. W. E. Thomas

44. E. T. Tomlinson

45. D. B. Trauger

46-56. D. R. Vondy

57. C. R. Weisbin

58. B. A. Worley

59. A. Zucker

60. P. Greebler (Consultant)

61. W. W. Havens (Consultant)

62. A. F. Henry (Consultant)

63. R. E. Uhrig (Consultant)

64-65. Central Research Library

66. Y-12 Document Reference Section

67-68. Laboratory Records Department

69. Laboratory Records, ORNL RC

70. ORNL Patent office

\section{EXTERNAL DISTRIBUTION}

DEPARTMENT OF ENERGY, Washingt on, D. C. 20545

71. J. W. Cunningham, Director, Nuclear Energy Programs

72. E. Beckjord, Director, Nuclear Power Development Division

73. K. O. Laughon, Assistant Director - HTGR Programs, NPDD

74. T. E. Collins, HTGR Programs, NPDD

75-79. K. A. Trickett, Assistant Director for Program Support, NPDD

DOE SENIOR PROGRAM COORDINATOR, SAN-SD, P. O. BoX 81325, San Diego, CA 92138

80. J. B. Radcliffe

DOE SAN FRANCISCO OPERATIONS OFFICE, 1333 Broadway, Wells Fargo Building, Oakland, CA 94612

81. Manager

DOE OAK RIDGE OPERATIONS OFFICE, P. O. BOX E, Oak Ridge, Tn. 37830

82. Director, Research and Technical Support Division

83. Director, Reactor Division

84. H. W. Behrman, Reactor Division

GENERAL ATOMIC COMPANY, P. 0. Box 81608, San Diego, CA 92138

85-88. E. O. Winkler 
GENERAL ELECTRIC COMPANY

89. C. Hussy, 1 River Road, Schenectady, N. Y. 12345

90. T. J. Korey, I River Road, Schenectady, N. Y. 12345

91. C. Cowan, Box 5020, Sunnyvale, CA 94086

92. C. Robertson, FBRD, Cincinnati, Ohio

OAR RIDGE ASSOCIATED UNIVERSITIES, Institute for Energy Ana1ysis,

P. O. Box 117, Oak Ridge, Tn. 37830

93. A. M. Perry

94. A. M. Weinberg

LOS ALAMOS SCIENTIFIC LABORATORY, BOX 1663, Los Alamos, NM 87545

95. R. Jiocoletti

96. C. Lee

INSTITUT FUR REAKTORENTWICKLUNG, KFA, 517 JüIich, Postfach 1913, West Germany

97. E. Teuchert

DOE TECHNICAL INFORMATION CENTER, P. O. BOX 62, Oak Ridge, Tn. 37830

98-274. For Distribution as shown in TID-4500 Distribution Category UC-77 (Gas-Cooled Reactor Technology). 